University of South Florida

DIGITAL COMMONS

@ UNIVERSITY OF SOUTH FLORIDA
Digital Commons @ University of

South Florida

8-1-2006

\title{
Using Local Transit On-Board Surveys for State-Level \\ Measurement
}

CUTR

Follow this and additional works at: https://digitalcommons.usf.edu/cutr_nctr

\section{Recommended Citation}

"Using Local Transit On-Board Surveys for State-Level Measurement," National Center for Transit Research (NCTR) Report No. CUTR-NCTR-RR-2004-14, Center for Urban Transportation Research, University of South Florida, 2006.

DOI: https://doi.org/10.5038/CUTR-NCTR-RR-2004-14

Available at: https://scholarcommons.usf.edu/cutr_nctr/177

This Technical Report is brought to you for free and open access by the National Center for Transit Research (NCTR) Archive (2000-2020) at Digital Commons @ University of South Florida. It has been accepted for inclusion in Research Reports by an authorized administrator of Digital Commons @ University of South Florida. For more information, please contact digitalcommons@usf.edu. 


\title{
Using Local Transit On-Board Surveys for State-Level Measurement
}

\author{
Center for Urban \\ Transportation Research \\ University of South Florida, Tampa \\ August 2006
}

Project Title: Standardize On-Board Surveys and Archive On-Board Survey Data

Contract Number: BD549-16 


\section{Disclaimer}

The opinions, findings, and conclusions expressed in this publication are those of the authors and not necessarily those of the State of Florida Department of Transportation. 


\section{Technical Report Documentation Page}

\begin{tabular}{|c|c|c|c|}
\hline $\begin{array}{l}\text { 1. Report No. } \\
\text { NCTR-576-07, BD549-16 }\end{array}$ & 2. Government Accession No. & \multicolumn{2}{|c|}{ 3. Recipient's Catalog No. } \\
\hline \multirow{2}{*}{\multicolumn{2}{|c|}{$\begin{array}{l}\text { 4. Title and Subtitle } \\
\text { Using Local Transit On-Board Surveys for State-Level Measurement }\end{array}$}} & \multicolumn{2}{|l|}{$\begin{array}{l}\text { 5. Report Date } \\
\text { August } 2006\end{array}$} \\
\hline & & \multicolumn{2}{|c|}{ 6. Performing Organization Code } \\
\hline \multicolumn{2}{|l|}{$\begin{array}{l}\text { 7. Author(s) } \\
\text { Xuehao Chu }\end{array}$} & \multicolumn{2}{|c|}{ 8. Performing Organization Report No. } \\
\hline \multirow{2}{*}{\multicolumn{2}{|c|}{$\begin{array}{l}\text { 9. Performing Organization Name and Address } \\
\text { National Center for Transit Research (NCTR) } \\
\text { University of South Florida } \\
\text { 4202 E Fowler Av, CUT 100, Tampa, FL 33620-5375 }\end{array}$}} & \multicolumn{2}{|l|}{ 10. Work Unit No. } \\
\hline & & \multicolumn{2}{|c|}{$\begin{array}{l}\text { 11. Contract or Grant No. } \\
\text { DTRS98-G-0032 }\end{array}$} \\
\hline \multirow{2}{*}{\multicolumn{2}{|c|}{$\begin{array}{l}\text { 12. Sponsoring Agency Name and Address } \\
\text { Office of Research and Special Programs } \\
\text { U.S. Department of Transportation, Washington, D.C. } 20590 \\
\text { Florida Department of Transportation } \\
605 \text { Suwannee Street, MS 30, Tallahassee, FL } 32399\end{array}$}} & \multicolumn{2}{|c|}{ 13. Type of Report and Period Covered } \\
\hline & & \multicolumn{2}{|c|}{ 14. Sponsoring Agency Code } \\
\hline \multicolumn{4}{|c|}{$\begin{array}{l}\text { 15. Supplementary Notes } \\
\text { Supported by a grant from the Florida Department of Transportation and the U.S. Department of } \\
\text { Transportation }\end{array}$} \\
\hline \multicolumn{4}{|c|}{$\begin{array}{l}\text { 16. Abstract } \\
\text { This report examines the feasibility of using local transit on-board surveys for state-level measurement of } \\
\text { a state's transit program policy objectives. It first sets up a general method using Florida as a case study } \\
\text { for its specific policy objectives. It then reviews in detail the design and administration of transit on-board } \\
\text { surveys in Florida. After comparing the general method and current practices, the report finally discusses } \\
\text { the challenges to using local on-board surveys for state-level measurement and proposes potential } \\
\text { solutions to overcome these challenges. Throughout the report, the focus is on those aspects of on- } \\
\text { board surveys that directly affect the feasibility of using local surveys for state-level measurement. These } \\
\text { aspects include survey questions, survey coverage, survey timing, and weighting of survey data for local } \\
\text { estimates and state-level measurement. While much of the analysis uses Florida as a case study, the } \\
\text { approach is applicable to other states that are interested in using local on-board surveys to monitor how } \\
\text { well their transit programs are achieving their state policy objectives. }\end{array}$} \\
\hline $\begin{array}{l}\text { 17. Key Words } \\
\text { Transit, On-Board Survey, Policy } \\
\text { Objectives, Florida, Choice } \\
\text { Riders, Captive Riders }\end{array}$ & $\begin{array}{l}\text { 18. Distribution Statement } \\
\text { Available to the public through th } \\
\text { Service (NTIS), } 5285 \text { Port Royal } \\
\text { 487-465, and through the NCTR }\end{array}$ & $\begin{array}{l}\text { ational Techn } \\
\text { dd, Springfield } \\
\text { site at http://v }\end{array}$ & $\begin{array}{l}\text { nation } \\
61,703- \\
\text { usf.edu }\end{array}$ \\
\hline $\begin{array}{l}\text { 19. Security Classif. (of this report) } \\
\text { Unclassified }\end{array}$ & $\begin{array}{l}\text { 20. Security Classif. (of this page) } \\
\text { Unclassified }\end{array}$ & $\begin{array}{l}\text { 21. No. of pages } \\
19 \text { (without } \\
\text { appendices) }\end{array}$ & 22. Price \\
\hline
\end{tabular}




\section{Executive Summary}

\section{Problem Statement and Objectives}

On-board surveys are conducted locally by public transit agencies to better understand their customers. While these surveys serve their primary local purposes, they can provide on-going information on transit markets at the state level for policy planning with little additional cost. There is a need to understand the feasibility of using these local on-board surveys for measuring the achievement of the State's transit program policy objectives at the state level.

Three objectives were established. The first objective was to develop a general method for using local systemwide on-board surveys of fixed-route transit services to measure the achievement of the State's transit program policy objectives. This method includes examining the policy objectives of the State's transit program, determining appropriate performance measures for these objectives, formulating appropriate survey questions for these measures, and developing an approach to aggregating local estimates for state-level measurement. The second objective was to review current practices of designing and administering on-board surveys in Florida, using existing documentations of most recent on-board surveys. The third objective was to compare the general method and the current practices, to discuss the challenges to using local transit on-board surveys for state-level measurement, and to propose potential solutions to overcome these challenges.

\section{Findings and Conclusions}

The general method of using local on-board surveys for state-level measurement is straightforward. As part of the transportation system, public transit in Florida helps improve the state's economic competitiveness and quality of life. Public transit accomplishes these overall goals in two ways. It expands modal choices to those who do have access to motor vehicles that they could have used to make the trips they currently make by transit (choice riders). In addition, it ensures basic mobility for people who do not have other options for those trips they make by transit (captive riders). The proposed question for defining choice riders is: Do you have a vehicle that you would have used to make this trip either as the driver or as a passenger? The proposed question for defining captive riders is: If transit were not available, would you have made this trip?

If unbiased local estimates of the shares of choice and captive riders are available and synchronized in time from all individual agencies, and agency-level weights are available for aggregation, state-level measurement is straightforward using the method of stratified sampling. However, a comparison of the general method with the practice of transit on-board surveys in Florida indicates many challenges to using local on-board surveys as practiced now in the state for state-level measurement.

One challenge is that local estimates are not always available because some on-board surveys do not ask the proposed questions. Besides encouragement and requiring all systemwide on-board surveys to include these two questions, one potential solution is to help agencies see the importance of knowing the sizes of its choice and captive markets. Equally important is to convince agencies that they need both of the proposed questions in order to correctly determine 
these markets. Two alternative practices that agencies have used to measure these markets do not work.

A second challenge is that local estimates are not synchronized in time with each other. Since transit development plans are not synchronized in Florida, requiring that a systemwide on-board survey be conducted as part of the major updates of these plans would not solve this problem. The only solution is to use the most recent available on-board surveys every time state-level measurement is desired. There are some problems with this solution. The relative timing of individual surveys may change over time. It is the difficult in labeling the result of state-level measurement in terms of a calendar year because the information from the local agencies is a mix of different years. However, these problems are minor.

The most serious challenge is that local estimates are biased sometimes. One source of biases is that the survey process does not always have systemwide coverage. Besides encouragement, it is important for transit agencies to understand that systemwide coverage means that the sampling process covers the entire system, but does not necessarily mean that they need to spend more resources on on-board surveys. Other biases can result from the design, sampling, and administration of an on-board survey. Biases may result from survey design when the design unit of analysis (persons, round trips, linked trips, or boardings) differs from the intended unit of analysis for each survey question. Biases may result from sampling when sampling is not random. Biases can also result from non-responses in survey administration. Appropriate weighting of raw survey data is critical for correcting these biases in local estimates. One urgent need in this area is a practical guide for transit agencies to avoid such biases in the first place and to develop weights for correcting each source of biases when they exist.

A related challenge is to come up with agency-level weights that are consistent across agencies for state-level aggregation. A starting point would be to use agency-level boardings as the weights. When the design unit of analysis varies across agencies and when this design unit of analysis is not boardings, boardings are not appropriate weights for this purpose. The suggested practical guide to be developed should also cover steps for agencies to develop agency-level weights under these circumstances.

\section{Benefits}

Florida invests heavily in public transit, and it is natural for the State to be interested in knowing the degree to which its public transit program is achieving the program policy objectives. When feasible, the State can use information from the local transit on-board surveys on an on-going basis to determine how well it is achieving its transit program policy objectives with little additional cost.

The State currently conducts the Customer Satisfaction Survey every two years through the Florida Department of Transportation. This survey contains a few questions on public transit. While this project did not focus on questions on transit customer satisfaction, the approach used in the report can be used to determine the feasibility of using customer satisfaction data from local transit onboard surveys to supplement the current Customer Satisfaction Survey on public transit. Unlike the questions related to the State's transit program policy objectives, every systemwide on-board survey has many questions on customer satisfaction. 


\section{Table of Contents}

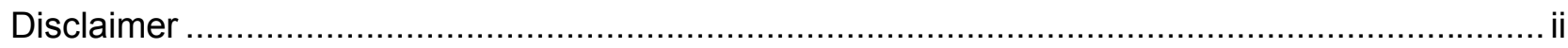

Technical Report Documentation Page ............................................................................

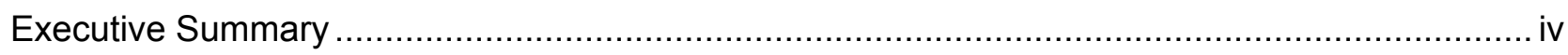

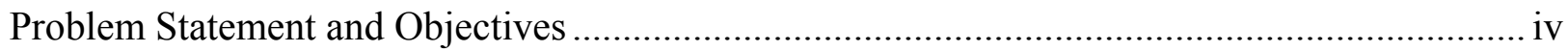

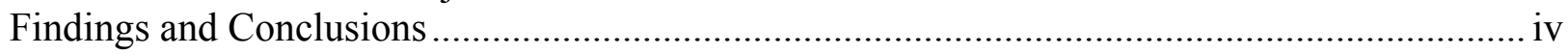

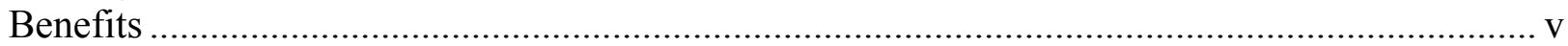

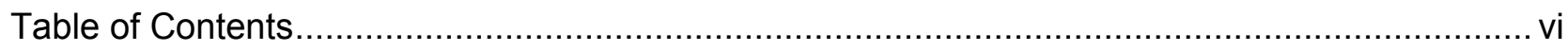

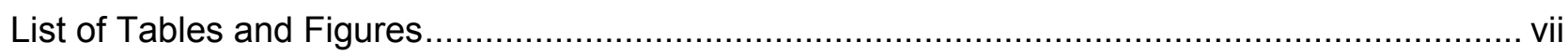

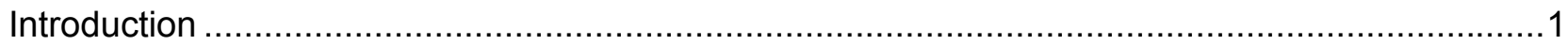

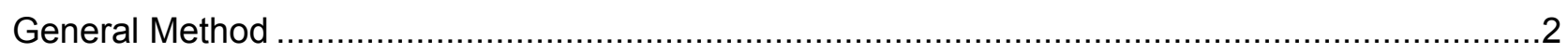

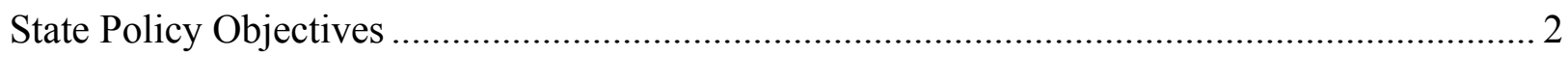

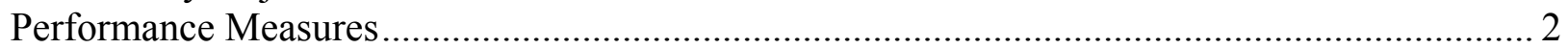

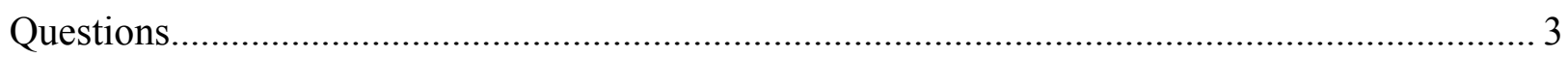

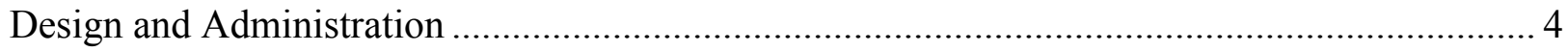

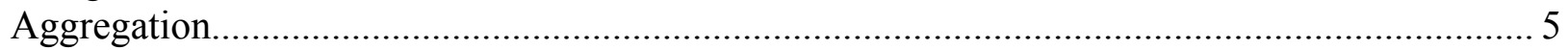

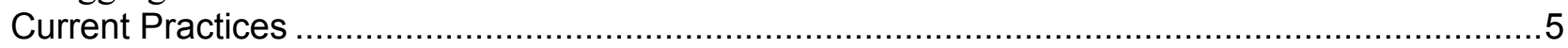

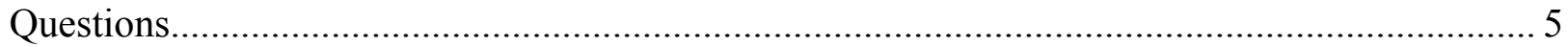

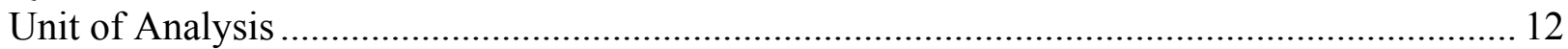

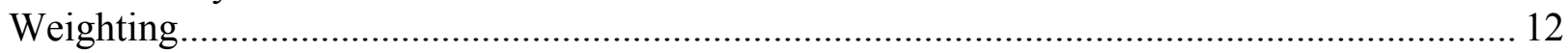

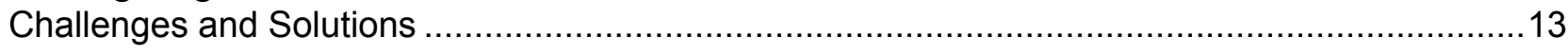

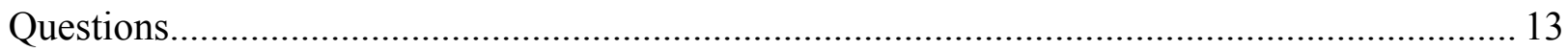

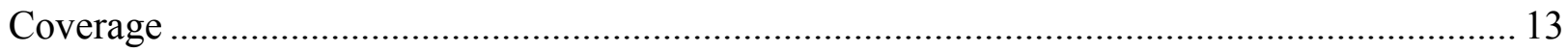

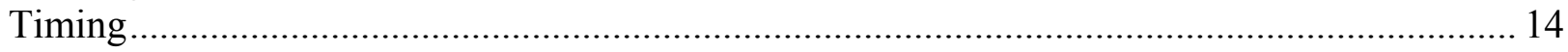

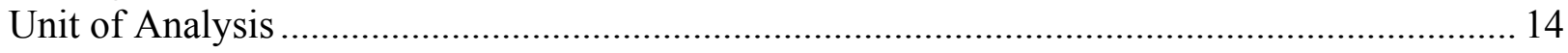

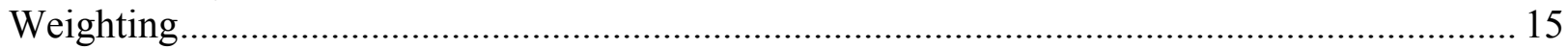

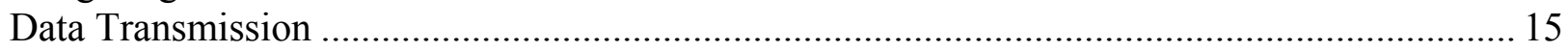

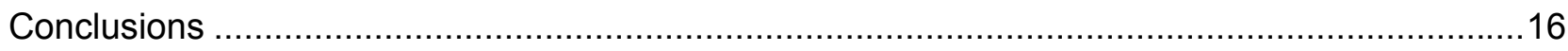

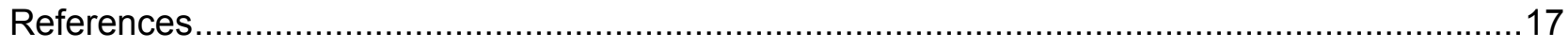

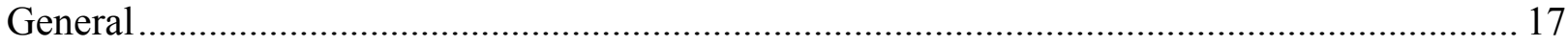

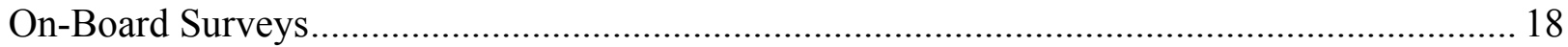

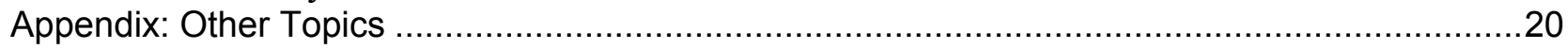

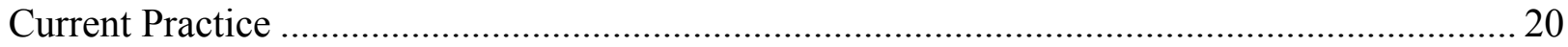

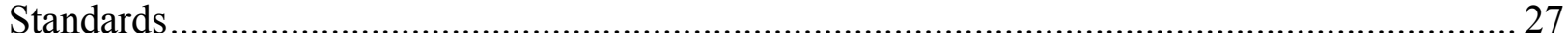

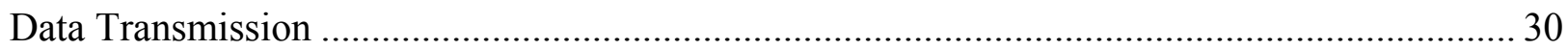




\section{List of Tables and Figures}

Table 1. Typical Question Wording and Response Categories ............................................. 6

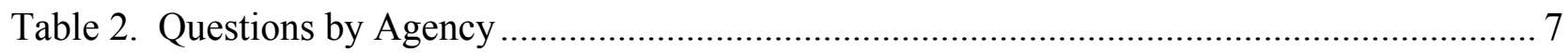

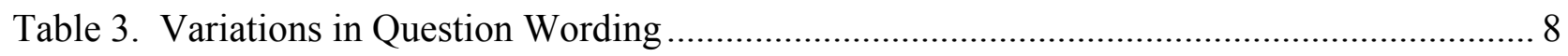

Table 4. Alternative Measurements of Captive and Choice Riders (Percent) ............................. 9

Table 5. Summary of Florida Practice on On-Board Surveys .............................................. 11

Table 6. Spreadsheet Template for Data Submission .......................................................... 16

Table 7. Coverage of Other Topic Areas ….................................................................... 21

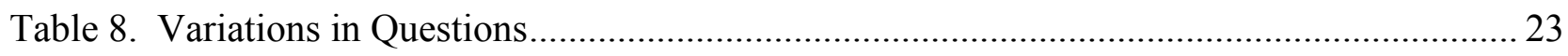

Table 9. Variations in Response Categories on Trip Purposes .............................................. 24

Table 10. Variations in Walk-Related Response Categories on Access/Egress .......................... 25

Table 11. Variations in Response Categories on Frequency of Transit Usage............................. 26

Table 12. Variations in Response Categories for Duration ................................................. 27

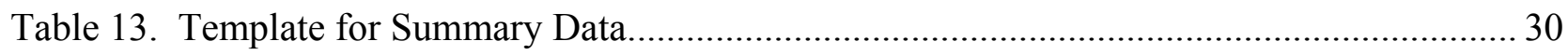

Table 14. Template for Summary Data on Origin-Destination Purposes ................................... 31 


\section{Introduction}

States invest heavily in public transit. In fiscal year 2003, the federal government spent $\$ 6.7$ billion while states spent close to $\$ 9$ billion on public transit (BTS 2004). It is natural for states to be interested in knowing the degree to which their public transit programs are achieving their program policy objectives. One problem is that relevant transit data are collected by sub-state agencies and governments. One common source of local transit data is on-board surveys, which are self-administered and distributed surveys or interviews conducted on board transit vehicles. Transit agencies frequently conduct on-board surveys on a variety of scales (individual routes, individual modes, corridors, service type, systemwide, or multiple systems in a region) and use data from them for modeling regional travel demand, route planning and scheduling, service design, marketing, and customer feedback (Schaller 2005). In addition, transit on-board surveys may be used for evaluating policies and programs (Teal and Nemer 1986; Labelle and Stuart 1995; USDOT 2002; Thakuriah et al. 2005) or for measuring travel parameters, including the distribution of access/egress distances (O'Sullivan and Morrall 1996), fare elasticities (Cervero 1982), transfer penalty (Guo and Wilson 2004), the distribution of cross-operator fare revenues (Richardson et al. 1998), etc. While these surveys serve their primary local purposes, they can potentially provide on-going information on transit markets at the state level for policy planning with little additional cost.

Beyond documenting the use of local transit on-board surveys for a variety of local purposes, the literature on on-board surveys is limited. Sheskin and Stoper (1982) compare response rates, missing responses to individual questions, and completeness of responses in responded questions across different approaches to administering an on-board survey. A few authors provide guidance on conducting on-board surveys (Retzlaff et al. 1985; Multisystems 1985; Elmore-Yalch 1998; Baltes 2002). Several review on-board survey practices (Chadda and Mulinazzi 1977; Dean 1980; Elmore-Yalch 1998; Potts 2002; Cronin, Jr. et al. 2004; Schaller 2005). This report contributes to the literature by examining the feasibility of using local transit on-board surveys for measuring the achievement of the public policy objectives of state transit programs.

The remainder of the report is organized into four sections. The first section describes a general method of using local systemwide on-board surveys of fixed-route transit services for state-level measurement. Specifically, it examines the policy objectives of the transit program in the State of Florida, determines appropriate performance measures for these objectives, formulates appropriate survey questions for these measures, and describes issues for administering on-board surveys with these questions and for aggregating local estimates for state-level measurement. The second section reviews current practices of designing and administering on-board surveys in Florida. After comparing the general method and the current practices, the report discusses the challenges to using local transit on-board surveys for state-level measurement and proposes potential solutions to overcome these challenges. The last section concludes the report. Throughout the report, the focus is on those aspects of on-board surveys that directly affect the feasibility of using local surveys for state-level measurement. These aspects include survey questions, survey coverage, survey timing, and weighting of raw survey data for local estimates and state-level measurement. While much of the analysis uses Florida as a case study, the approach is applicable to other states that are interested in using local on-board surveys to monitor how well their transit programs are achieving their state policy objectives. 


\section{General Method}

This section provides a general framework under which one would examine the policy objectives of a state's transit program, appropriate performance measures for these policy objectives, appropriate on-board survey questions to solicit information for these measures, the administration of on-board surveys that include these questions, and the aggregation of the local data for statelevel measurement. The discussion is done in the context of the State of Florida.

\section{State Policy Objectives}

The State of Florida currently commits a minimum investment of 15 percent of the State Transportation Trust Fund to public transportation, including aviation, intermodal, rail, and public transit (Florida Senate 2001). The State sees public transit as an important policy instrument for a stronger economy and an enriched quality of life (s. 334, Florida Statutes; Florida Senate 2001; FDOT 2004; FDOT 2005a; FDOT 2005b). Public transit helps the State to accomplish these broad policy goals mainly through two policy objectives. It expands modal choices to those who do have access to motor vehicles at the time when they make transit trips. In expanding these modal choices for people who do have access to motor vehicles, transit may, in turn, help the State reduce its reliance on motor vehicles for passenger travel and potentially reduce the need to expand highway facilities. In addition, public transit ensures basic mobility for people who do not have other options for those trips they make by transit.

\section{Performance Measures}

In general, the achievement of a state's transit policy objectives may be measured directly at the highest level, i.e., improvements in the state's economic competitiveness and quality of life. This approach to performance measurement has two serious problems. Many other public policies influence the state's economic competitiveness and quality of life, and public transit's role is relatively small. As a result, it is statistically difficult to measure transit's role reliably. In addition, there are no clear measures to quantify how transit helps in improving the state's economic competitiveness and quality of life.

Alternatively, one may measure the achievement of a state's transit policy goals at the level of the entire transportation system. In assessing the performance of the Florida Department of Transportation's public transportation program, the Florida Legislature's Office of Program Policy Analysis and Government Accountability (OPPAGA) recommended measures that provide important policy information. Specifically, it recommended considering transit's mode share for the commuting market (OPPAGA 1999). While this measure captures the effect of providing modal options to whose who do have access to motor vehicles and the effect of providing basic mobility to those who do not have other options, this measure would require data that would not be available from typical transit on-board surveys.

With on-board surveys, transit's policy objectives can be measured at a level at which transit makes a direct impact on providing travel choices and basic mobility. On providing travel choices, one primary measure would be the percent of riders who have access to a motor vehicle that they could have used to make a particular trip either as a driver or as a passenger. For lack of a better term, this report will follow the industry convention and refer to these riders as "choice" riders. In 
fact, APTA (2006) defines a choice rider as "a person who has at least two modes of travel available and selects one to use." It is important to define choice at the individual trip level. Workers who usually commute to work by a motor vehicle, for example, would still use transit occasionally (Polzin and Chu 2005).

If transit were not available, riders who would not have made the particular trip at the same time would still have two options. One is to make the trip with another mode at another time, and the other option is to forgo the related activity completely. One possible measure for transit captivity would only include those riders who would forgo the related activity completely. However, this report proposes to use a more conventional measure that covers both of these options: the percent of riders who would not have made a particular trip if transit were not available. Again, for lack of a better term, this report will follow the convention of the transit industry and refer to these riders as "captive" riders. In fact, APTA (2006) defines a captive rider as "a person who does not have a private vehicle available or cannot drive (for any reason) and who must use transit to make the desired trip."

It is more important to define captivity than to define choice at the individual trip level. People living in zero-vehicle households proportionally make far more trips by motor vehicles than by transit (Schaller 2005). Also, workers who usually commute to work by transit still drive or ride as a passenger frequently (Polzin and Chu 2005).

Using data from pilot tests of the Transit Performance Monitoring System (TPMS) to measure the degree to which transit is achieving the policy objectives at the federal level, transit's role in serving the mobility objective was defined narrower than what is being proposed here (McCollom Management Consulting 2004). Specifically, captivity was limited to riders who had no working vehicle available for the trip. This narrow definition excludes riders who do have vehicles available at the time of making a trip but, for whatever reason, do not drive.

\section{Questions}

With these two specific measures for the two corresponding policy objectives of public transit, it is straightforward to develop on-board survey questions to solicit information for these two measures. The following question is proposed for measuring the percent of choice riders: Did you have access to a motor vehicle that you could have used to make this trip either as the driver or a passenger? To measure the percent of captive riders, the following question is proposed: If transit were not available, would you have made this trip?

The matter actually is not as simple as it sounds because it is not necessarily clear what "this trip" means in these two questions. "This trip" is frequently used in transit on-board surveys, but it may mean different things in different questions by design. When "transferred" is used as a response category, "this trip" in the question "How did you get to the stop for this trip?" refers to an unlinked trip. In asking about the total number of transfers required, on the other hand, "this trip" means a linked trip. Similarly, "this trip" means a linked trip in the question on origin purposes: "Where are you going on this trip?" In the particular context of the two proposed questions, however, "this trip" can mean the linked one-way trip but is really referring to the round trip. This is particularly true in terms of the question on whether one would still make the trip if transit were not available: once leaving home in the morning, not going back home in the afternoon is not an 
option in most cases. At the same time, respondents may have difficulty in understanding what "this trip" means even in a given question (Schaller 2005). This confusion about "this trip" can be cleared if qualifications are added to survey questions. But it is clear from past experience that it is highly desirable to keep on-board survey questions simple (Schaller 2005).

\section{Design and Administration}

When appropriately designed and administered, data from local on-board surveys with these two questions can be used to get local estimates of the proposed performance measures on transit's policy objectives. Sample size and sampling errors at the agency level are not the most important factors for getting unbiased state-level measurement. Once pooled, the combined sample would lead to more than sufficient precision and confidence levels. A number of other aspects of survey design and administration, however, could directly affect the feasibility of using local survey data for state-level measurement.

Coverage. Unbiased state-level measurement requires that local on-board surveys be designed to have systemwide coverage of all fixed-route services.

Timing. Ideally, state-level measurement should be based on local on-board surveys that are synchronized in time. This timing consistency includes the first year at which such measurement starts and subsequent years.

Unit of Analysis. Local estimates need to be based on the same design unit of analysis. The design unit of analysis of an on-board survey can be persons, linked trips, or unlinked trips (Schaller 2005). Regardless of how many linked trips a rider makes during a survey period, if he fills a survey form only the first time he is asked during the survey period, the design unit of analysis is individual riders. If the same person is asked to fill a survey form every time he is encountered, the design unit of analysis is individual boardings made by the riders. Otherwise, the same person is asked to fill a survey form once for each origin-destination trip, and the design unit of analysis is individual linked trips.

The design unit of analysis for an on-board survey needs to be the same as the intended unit of analysis for the questions asked. Suppose the questions are to solicit information about individual linked trips, but the design unit is individual boardings. Then transit riders who transfer are going to be over-represented in the raw data relative to those who do not transfer. Similarly, agencies whose route structure requires more transfers are going to be over-represented in the raw data relative to agencies with a simpler route structure.

Weighting. Biases may exist in the raw survey data at the agency level due to non-randomness in the received surveys. Non-randomness may result, for example, from sampling not being random or non-responses not being random. The raw survey data need to be appropriately weighted to correct for such systematic biases before the raw data are used to get the local estimates. In addition, systematic biases resulting from a mismatch between the design unit of analysis and the intended unit of analysis for the questions need to be corrected through weighting. In the case where the questions are to solicit information about individual linked trips, but the design unit is individual boardings, the number of transfers obtained from the same survey would need to be used to correct for this bias at the respondent level. 


\section{Aggregation}

Aggregating local estimates to state-level measures becomes easy if one recognizes that the method of stratified sampling applies here (Cochran 1977). For ease of discussion, suppose the design unit of analysis is individual boardings. The state-level population of boardings consists of the sub-populations of boardings at the individual agencies. These sub-populations are mutually exclusive and together they comprise the whole state-level population. Consider a state that has $J$ agencies indexed with $j=1,2, \ldots, J$. At year $t$, agency $j$ conducts a systemwide on-board survey of its fixed-route boardings. The raw data from a policy question in the survey can be used to get an unbiased estimate of the proportion of the boardings with certain characteristic of the subpopulation at agency $j, s_{j}^{t}$. An example would be the proportion of boardings made by females.

The method of stratified sampling shows that if the local estimates $s_{j}^{t}(j=1,2, \ldots, J)$ are unbiased for every agency, an unbiased estimate at the state-level at year $t$ is given by

$$
S^{t}=\sum_{j} w_{j}^{t} s_{j}^{t}
$$

where $w_{j}^{t}$ is agency $j$ 's share of state-level population of boardings. It is important to point out that equation (1) requires that the local estimates and the weights are based on the same unit of analysis.

\section{Current Practices}

This section examines the current practice of transit on-board surveys in Florida. As reviewed by Schaller (2005), transit on-board survey techniques in general are broad in scope and scale. This examination focuses on those aspects of the practice that are expected to have a great influence on the feasibility of using local estimates from these surveys for state-level measurement as described in the last section. While Schaller (2005) relied on a survey of agencies for his review, information on the current practice in Florida is obtained from written documentations of the most recent transit on-board surveys from 25 transit agencies operating fixed-route services. Most of these documentations are part of a transit development plan, and others are from on-board survey reports, market research reports, operations plans, etc. The individual documents are not cited here, but are listed in References on On-Board Surveys after the other references.

\section{Questions}

Three types of questions are included in some of the on-board surveys that are related to Florida's policy objectives. They are questions related to alternative modes for a particular trip (Q1), vehicle availability for a particular trip (Q2), and reasons for using transit in general (Q3). Table 1 shows how these questions are typically worded and what response categories are typically used. 
Table 1. Typical Question Wording and Response Categories

\begin{tabular}{|l|l|}
\hline \multicolumn{1}{|c|}{ Wording } & \multicolumn{1}{c|}{ Response Categories } \\
\hline \multirow{4}{*}{$\begin{array}{l}\text { Q1 (Alternative Modes): How would you make this trip if not } \\
\text { by transit? }\end{array}$} & Drive \\
\cline { 2 - 2 } & Ride with someone \\
\cline { 2 - 2 } & Walk \\
\cline { 2 - 2 } & Bicycle \\
\cline { 2 - 2 } & Taxi \\
\cline { 2 - 2 } Q2 (Vehicle Availability): Do you have a car or other person't make trip \\
\cline { 2 - 2 } vehicle that you could have used to make this trip? & Other (specify) \\
\hline \multirow{5}{*}{$\begin{array}{l}\text { Q3 (Reasons for Using Transit): What is the most important } \\
\text { reason you take transit? }\end{array}$} & No \\
\cline { 2 - 2 } & I don't drive \\
\cline { 2 - 2 } & Car is not available \\
\cline { 2 - 2 } & Transit is more economical \\
\cline { 2 - 2 } & Transit is more convenient \\
\cline { 2 - 2 } & Traffic is too bad \\
\cline { 2 - 2 } & Other \\
\hline
\end{tabular}

The vehicle availability question is similar to what was proposed earlier to determine whether someone is a choice rider. However, it lacks the qualification used in the proposed question that the rider can use the available vehicle either as the driver or as a passenger. To the extent that respondents interpret this question to mean that they could have used that available vehicle as the driver only, this question would understate the number of choice riders. For the alternative modes question, those who respond with "Wouldn't make trip" presumably would respond with a "no" to the question proposed earlier in the report: "If transit were not available would you make this trip?" In both cases, transit was the only option. The question on reasons for using transit is discussed later in this sub-section.

Issues. There are several issues in the practice that makes it harder to use data from local surveys for state-level measurement. First, not all agencies ask both questions. Table 2 shows the specific questions each agency used in its most recent survey. Five of the 25 agencies do not ask any of these questions, including Indian River County Transit, LYNX, Miami-Dade Metrobus, Pinellas County Transit, and Tri-Rail. Three agencies use all three questions, including Bay County Trolley, Hernando County Transit, and Volusia County Transit. Other agencies use 1 or 2 of these questions. In addition, 17 of the 25 agencies use the question on alternative modes and 18 use the question on reasons for using transit, but only 5 agencies use the question on vehicle availability. To indicate the relative influence of a particular agency on state-level measurement, the annual number of fixed-route boardings for FY2003 is also included for agencies that reported their ridership data to the National Transit Database (FDOT, 2005c). 
Table 2. Questions by Agency

\begin{tabular}{|l|r|c|c|c|c|}
\hline Agencies & \multicolumn{1}{|c|}{$\begin{array}{c}\text { FY2003 } \\
\text { Boardings }\end{array}$} & Count & $\begin{array}{c}\text { Q1: } \\
\text { Alternative } \\
\text { Modes }\end{array}$ & $\begin{array}{c}\text { Q2: } \\
\text { Vehicle } \\
\text { Availability }\end{array}$ & $\begin{array}{c}\text { Q2: } \\
\text { Reasons } \\
\text { for Using } \\
\text { Transit }\end{array}$ \\
\hline Bay County Trolley & 105,749 & 3 & 1 & 1 & 1 \\
\hline Brevard County Transit & 618,924 & 2 & 1 & & 1 \\
\hline Broward County Transit & $35,912,736$ & 1 & & 1 & \\
\hline Collier County Transit & N/A & 1 & & & 1 \\
\hline Escambia County Transit & $1,627,028$ & 2 & 1 & & 1 \\
\hline Gainesville Transit & $8,103,120$ & 1 & & 1 & \\
\hline Hernando County Transit & N/A & 3 & 1 & 1 & 1 \\
\hline Hillsborough County Transit & $9,185,410$ & 2 & 1 & & 1 \\
\hline Indian River County Transit & 205,571 & 0 & & & \\
\hline Jacksonville Transit (bus) & $8,484,871$ & 2 & 1 & & 1 \\
\hline Jacksonville Transit (skyway) & 503,698 & 1 & 1 & & \\
\hline Key West Transit & N/A & 2 & 1 & & 1 \\
\hline Lakeland Transit & $1,510,481$ & 1 & & & 1 \\
\hline Lee County Transit & $2,335,842$ & 2 & 1 & & 1 \\
\hline Lynx & $21,894,985$ & 0 & & & \\
\hline Manatee County Transit & $1,195,449$ & 2 & 1 & & 1 \\
\hline Martin County Transit & N/A & 1 & 1 & & \\
\hline Miami-Dade County Transit (Bus) & $64,546,632$ & 0 & & & \\
\hline Miami-Dade County Transit (Rail) & $14,306,084$ & 1 & & & 1 \\
\hline Okaloosa County Transit & 96,795 & 2 & 1 & & 1 \\
\hline Palm Beach County Transit & $7,199,527$ & 2 & 1 & & 1 \\
\hline Pasco County Transit & 463,409 & 2 & 1 & & 1 \\
\hline Pinellas County Transit & $9,487,531$ & 0 & & & \\
\hline Sarasota County Transit & $1,718,370$ & 2 & 1 & & 1 \\
\hline Tallahassee Transit & $4,372,762$ & 2 & 1 & & 1 \\
\hline Tri-Rail & $2,725,142$ & 0 & & & \\
\hline Volusia County Transit & $2,836,863$ & 3 & 1 & 1 & 1 \\
\hline Total & N/A & & 17 & 5 & 18 \\
\hline
\end{tabular}

Second, the same question is worded differently across agencies (Table 3). Each question has a preferred way of being worded among the agencies. For the alternative modes question, five of the six variations are similar in that they all use multiple response categories. The last one in the list, "Do you have another option to make this trip if not by transit?" is a yes-no question. In this sense, it is similar to the question proposed earlier in this report for measuring transit's objective of providing basic mobility. However, the results from its one-time use by Pasco County Transit make it suspicious whether this question is capturing what it is designed to. Specifically, about 71 percent of 283 riders of Pasco County Transit said in a 2005 on-board survey that they did not have another option (Tindale-Oliver \& Associates 2005b). This is extremely high relative to what other agencies are getting using the other variations of the question. More is discussed next on this in the context of what is the best way to ask about transit choice and captivity. 
Table 3. Variations in Question Wording

\begin{tabular}{|c|c|c|}
\hline $\begin{array}{l}\text { Question } \\
\text { Type }\end{array}$ & Variations & $\begin{array}{c}\text { Number of } \\
\text { Surveys } \\
\text { Using }\end{array}$ \\
\hline \multirow{6}{*}{$\begin{array}{l}\text { Q1: } \\
\text { Alternative } \\
\text { Modes }\end{array}$} & How would you make this trip if not by transit? & 12 \\
\hline & How would you make this trip if there was no transit? & 1 \\
\hline & If you could not take transit, how would you make this trip? & 1 \\
\hline & How would you make this trip if transit was not available? & 1 \\
\hline & When you do not use transit to make this trip, how do you travel? & 1 \\
\hline & Do you have another option to make this trip if not by transit? & 1 \\
\hline \multirow{3}{*}{$\begin{array}{l}\text { Q2: } \\
\text { Vehicle } \\
\text { Availability }\end{array}$} & $\begin{array}{l}\text { Do you have a car or other personal vehicle that you could have used to } \\
\text { make THIS trip? }\end{array}$ & 3 \\
\hline & Did you have a vehicle available to make this trip? & 1 \\
\hline & Was a car available for THIS trip? & 1 \\
\hline \multirow{4}{*}{$\begin{array}{l}\text { Q3: } \\
\text { Reasons for } \\
\text { Using } \\
\text { Transit }\end{array}$} & What is the most important reason you ride the bus? & 12 \\
\hline & $\begin{array}{l}\text { Compared to other transportation alternatives available to you, what is } \\
\text { the most important reason you use transit? }\end{array}$ & 4 \\
\hline & Why did you take transit for this trip? & 1 \\
\hline & Which is your one most important purpose for taking the bus today? & 1 \\
\hline
\end{tabular}

Alternatives Questions. Some agencies use data from the question on reasons for using transit (Q3) to measure whether its riders are transit choice or captive. Specifically, they define those riders whose most important reason for using transit is "Transit is more economical" or "Transit is more convenient" or "Traffic is too bad," etc. as choice riders. Further, they define those riders whose most important reason for using transit is "I don't drive," "Car is not available," or "I don't have a valid drivers' license" as captive riders. They use this question either in addition to the questions on alternative modes (Q1) and vehicle availability (Q2) or in place of them. However, this practice is not a reliable approach to defining choice and captive riders.

Some agencies use the alternative modes question to measure choice riders. In addition to the category of "Wouldn't make trip," this question typically includes "Drive" and "Ride with someone" as additional alternative modes. As discussed above, the response category of "Wouldn't make trip" can be used to measure the captive market. But this alternative practice also wants to use those who choose "Drive" or "Ride with someone" to define choice riders. While this question is trip-specific, the problem is that the choice measured is not between taking transit and using a motor vehicle. The choice in such a measurement is between using a motor vehicle and other non-transit options.

Table 4 compares the results on the percent of choice riders and the percent of captive riders measured with the proposed questions versus with the alternative questions. Specifically, the percent of choice riders is measured with the vehicle availability question (proposed, Q2) and the other two questions (alternatives, Q1 and Q3), respectively. Similarly, the percent of captive riders is measured with the alternative modes question (proposed, Q1) and the question on reasons for using transit (alternative, Q3), respectively. To deal with variations in the response categories 
for the question on reasons for using transit, the percent of captive riders is determined first, and the remaining of the 100 percent is assumed to be choice riders. Note that these results are directly taken from the documents describing the individual on-board surveys and results.

Table 4. Alternative Measurements of Choice and Captive Riders (Percent)

\begin{tabular}{|c|c|c|c|c|c|}
\hline \multirow[b]{2}{*}{ Agency } & \multicolumn{2}{|c|}{ Captive Riders } & \multicolumn{3}{|c|}{ Choice Riders } \\
\hline & $\begin{array}{l}\text { Using Q1: } \\
\text { Alternative } \\
\text { Modes }\end{array}$ & $\begin{array}{c}\text { Using Q3: } \\
\text { Reasons } \\
\text { for Using } \\
\text { Transit }\end{array}$ & $\begin{array}{c}\text { Using Q1: } \\
\text { Alternative } \\
\text { Modes }\end{array}$ & $\begin{array}{c}\text { Using Q2: } \\
\text { Vehicle } \\
\text { Availability } \\
a\end{array}$ & $\begin{array}{c}\text { Using Q3: } \\
\text { Reasons } \\
\text { for Using } \\
\text { Transit }\end{array}$ \\
\hline Bay County Trolley & 20 & 72 & 25 & & 28 \\
\hline Brevard County Transit & 22 & 78 & 40 & & 22 \\
\hline Broward County Transit & & & & 12 & \\
\hline Collier County Transit & & 75 & & & 25 \\
\hline Escambia County Transit & 16 & 61 & 49 & & 39 \\
\hline Gainesville Transit & & & & 51 & \\
\hline Hernando County Transit & 32 & 79 & 36 & 25 & 21 \\
\hline Hillsborough County Transit & 16 & 72 & 46 & & $28^{b}$ \\
\hline Jacksonville Transit (bus) & 17 & 62 & 51 & & 38 \\
\hline Jacksonville Transit (skyway) & 5 & & 50 & & \\
\hline Key West Transit & 5 & 73 & 40 & & 27 \\
\hline Lakeland Transit & & 85 & & & 15 \\
\hline Lee County Transit & 26 & 66 & 43 & & 34 \\
\hline Manatee County Transit & 14 & 77 & 40 & & 33 \\
\hline Martin County Transit & 35 & & 38 & & \\
\hline Miami-Dade County Transit (Rail) & & 35 & & & $65^{c}$ \\
\hline Okaloosa County Transit & 15 & 79 & 36 & & 21 \\
\hline Palm Beach County Transit & 14 & 78 & 48 & & 22 \\
\hline Pasco County Transit & 71 & 75 & & & 25 \\
\hline Sarasota County Transit & 16 & 80 & 41 & & 20 \\
\hline Tallahassee Transit & 10 & 71 & 39 & & 29 \\
\hline Volusia County Transit & 16 & 84 & 39 & 22 & 16 \\
\hline
\end{tabular}

${ }^{\text {a }}$ Bay County Trolley did ask the question on vehicle availability but did not show the results.

b The question was day-specific: "Which is your one most important purpose for taking the bus today?" "I don't drive" and "I don't have a valid drivers' license" are not listed as reasons.

${ }^{c}$ The question was trip-specific: "Why did you take Metrorail for this trip? "I don't drive" and "I don't have a valid drivers' license" are not listed as reasons.

The evidence on the reasonableness of estimating the percent of choice riders with the question on reasons for using transit is limited. While Table 4 shows an estimate from the question on reasons for using transit for each of the 18 agencies that use this question, it only shows two matching estimates from the question on vehicle availability (Hernando County and Volusia County). In both cases, the estimate from the question on reasons for using transit is smaller than the correct 
estimate from the vehicle availability question. Given the problems with the question on reasons for using transit, however, one must have little confidence in any estimate of the percent of choice riders from its data.

The evidence on the reasonableness of estimating the percent of choice riders with the alternative modes question also is limited. Based on the alternative modes question, an estimate is available for 15 agencies. Choice riders vary from 25 percent in Bay County Transit to 51 percent in Jacksonville bus, and are about 40 percent for the majority of agencies. Again, matching estimates are available between the vehicle availability question and this alternative modes question for only two agencies (Hernando County and Volusia County). In both cases, however, the estimate from the alternative modes question is significantly higher than the correct estimate from the vehicle availability question.

There is more evidence on the reasonableness of estimating the percent of captive riders with the question on reasons for using transit. Based on the alternative modes question, on one hand, captive riders vary from 5 percent in Key West to 35 percent in Martin County, with Pasco County at 71 percent as an exception. As mentioned earlier, this estimate of a large percent of captive riders in Pasco County was based on a question worded quite differently from the others and does not seem to be reasonable, casting doubts on the particular wording of this question. Based on the question on reasons for using transit, on the other hand, captive riders represent 35 percent on the Miami-Dade Metrorail, but much higher shares on the bus systems with the majority in the 70 s and 80 s. This overestimation of the percent of captive riders from the question on reasons for using transit does not result from respondents picking multiple response categories. Respondents are always asked to choose one reason only. The main reason for the high percentages is that this question is asked generally rather than specific to the subject trip. In contrast, it is desirable to define captivity at the trip level, and the alternative modes question is specific to the subject trip.

\section{Coverage}

When conducted, transit on-board surveys almost always are systemwide with two exceptions (Table 5). In its most recent on-board survey in 2003, Broward County Transit focused on its 10 most heavily-used routes, representing one quarter of the systemwide routes but 48 percent of its systemwide ridership. Miami-Dade Transit, on the other hand, focused its most recent on-board survey to its Metrobus and Metrorail services but excluded its Metromover from this survey. The 2000 Southeast Florida Regional Travel Characteristics Study also excluded Metromover in its transit on-board survey of the entire Southeast Florida region (Carr Smith Corradino 2000). 
Table 5. Summary of Florida Practice on On-Board Surveys

\begin{tabular}{|c|c|c|c|c|c|c|c|}
\hline \multirow[b]{2}{*}{ Agency } & \multirow[b]{2}{*}{$\begin{array}{l}\text { System- } \\
\text { wide }\end{array}$} & \multicolumn{4}{|c|}{ Timing } & \multirow{2}{*}{$\begin{array}{c}\text { Design } \\
\text { Unit of } \\
\text { Analysis }\end{array}$} & \multirow[b]{2}{*}{ Weighting } \\
\hline & & $T D P$ & $\begin{array}{c}\text { Most } \\
\text { Recent } \\
\text { \& Docu. }\end{array}$ & $\begin{array}{c}\text { Year of Recent } \\
\text { Known Surveys }\end{array}$ & Interval (years) & & \\
\hline Bay County Trolley & Yes & Yes & 2005 & $96,98,02,05$ & $2-4$ & $\mathrm{UT}^{\mathrm{d}}$ & Yes \\
\hline Brevard County Transit & Yes & No & 2004 & 99,04 & 5 & UT & $\mathrm{c}$ \\
\hline Broward County Transit & No & Yes & 2003 & $96,97,03$ & $1-6$ & & No \\
\hline \multicolumn{8}{|l|}{ Charlotte County ${ }^{\mathrm{a}}$} \\
\hline Collier County Transit & Yes & Yes & 2005 & 02,05 & 3 & UT & \\
\hline Escambia County Transit & Yes & Yes & 2005 & $98,02,05$ & $3-4$ & UT & No \\
\hline Gainesville Transit & Yes & No & 2001 & 01 & & UT & \\
\hline Hernando County Transit & Yes & No & 2003 & 03 & & UT & No \\
\hline Hillsborough County Transit & Yes & No & 2001 & 97,01 & 4 & Riders & Yes \\
\hline Indian River County Transit & Yes & Yes & 2005 & $99,02,05$ & 3 & & \\
\hline Jacksonville Transit & Yes & Yes & 2004 & 99,04 & 5 & & \\
\hline Key West Transit & Yes & Yes & 1999 & 92,99 & 7 & UT & Yes \\
\hline Lakeland Transit & Yes & No & 1997 & 97 & & UT & No \\
\hline Lee County Transit & Yes & Yes & 2003 & $94,97,00,03$ & 3 & UT & Yes \\
\hline Lynx & Yes & No & 2001 & $95,98,01$ & 3 & UT & \\
\hline Manatee County Transit & Yes & Yes & 2004 & $90,94,98,01,04$ & $3-4$ & UT & \\
\hline Martin County Connector & Yes & Yes & 2004 & 04 & & & No \\
\hline Miami-Dade County-Rail & \multirow{3}{*}{ No } & No & 2005 & 05 & & & Yes \\
\hline Miami-Dade County-Bus & & No & 2004 & 04 & & & Yes \\
\hline \multirow{2}{*}{\multicolumn{8}{|c|}{$\begin{array}{l}\text { Miami-Dade County-Mover } \\
\text { Ocala Transit }^{\text {a }}\end{array}$}} \\
\hline & & & & & & & \\
\hline Okaloosa County & Yes & Yes & 2005 & 02,05 & 3 & UT & No \\
\hline Palm Beach County Transit & Yes & Yes & 2003 & $99,03,06$ & $4^{b}$ & & \\
\hline Pasco County Transit & Yes & Yes & 2005 & $99,02,05$ & 3 & UT & \\
\hline Pinellas County Transit & Yes & No & 2004 & 01,04 & 3 & & \\
\hline \multicolumn{8}{|l|}{ Polk County Transit ${ }^{\text {a }}$} \\
\hline Sarasota County Area Transit & Yes & Yes & 2002 & 98,02 & 4 & Riders & \\
\hline St. Johns County & Yes & Yes & 2006 & 06 & $\mathrm{~b}$ & & \\
\hline Tallahassee Transit & Yes & Yes & 2004 & $97,99,04$ & $2-5$ & UT & \\
\hline Tri-Rail & Yes & & 2004 & 00,04 & 4 & & \\
\hline Volusia County Transit & Yes & Yes & 2002 & $99,02,06$ & $3-4^{b}$ & UT & Yes \\
\hline
\end{tabular}

${ }^{a}$ No known on-board survey has been conducted.

${ }^{\mathrm{b}}$ A newer on-board survey has been conducted but has not been documented.

${ }^{c}$ An empty cell in the table indicates that it cannot be determined from the documentation. However, the empty ones are mostly likely to be UT for the design unit of analysis, and are most likely to be No on whether weighting is used.

${ }^{\mathrm{d}} \mathrm{UT}=$ boardings. 


\section{Timing}

The year in which the most recent on-board survey was conducted varies from 1997 to 2006 (Table 5). Three agencies (Palm Beach County Transit, the Sunshine Bus in St. Johns County, and Volusia County Transit) conducted new on-board surveys in 2006 but have not documented the results. Eighteen agencies conducted on-board surveys in the three years from 2003 to 2005. Five agencies conducted their most recent surveys before 2003, including Lakeland Transit in 1997, Key West in 1999, and Gainesville, Hillsborough, and LYNX in 2001. Two agencies, Charlotte County Transit and Ocala County Transit, do not appear to have conducted any on-board surveys.

The interval between two consecutive on-board surveys also varies across agencies. For five agencies, the documentation of the most recent on-board surveys does not give enough information to determine the interval between the most recent two surveys. For the other agencies that have conducted at least one on-board survey, the interval does not stay constant over time and ranges from 1 to 7 years for all agencies but ranges about 3-4 years for most of them. Whether on-board surveys are done as part of preparing a transit development plan does not seem to matter regarding when the most recent survey was conducted or the interval between surveys.

\section{Unit of Analysis}

The most recent surveys by Hillsborough County Transit and Sarasota County Transit are the only two that are specifically designed to not get more than one response from the same person (Table 5). This means that the design unit of analysis is individual riders rather than boardings or linked trips that these riders make. On the other hand, 14 agencies specifically designed their survey procedures to ask for a response from passengers every time they are being approached. While the documentation of the surveys does not explicitly discuss the related procedure, it is most likely that the remaining agencies followed the same procedure. This means that the design unit of analysis is individual boardings. The experience from Hillsborough County Transit shows that 28 percent of 10,796 boarding riders who were approached and asked to complete a survey form had already been approached during a 10-day survey period (Clark 2001).

\section{Weighting}

Among the 25 agencies that have conducted and documented on-board surveys, only 7 explicitly weighted the raw data from the surveys in studying their riders (Table 5). While not explicitly stating that the raw data were not weighted, it is determined that six agencies did not weight their raw survey data by examining how the documentation discusses the results. One good indication that weighting was not used is this: " 21 percent of the respondents did not have a vehicle available that they could have used to make this trip." While it is uncertain whether the raw data were weighted by the other agencies, it is most likely that weighting was not done. When weighting was used, however, the number of boardings is always the basis for weighting. 


\section{Challenges and Solutions}

If unbiased estimates of measures for these policy objectives are available and synchronized in time from all individual agencies, and if agency-level weights are available for state-level aggregation, state-level measurement is straightforward using the method of stratified sampling. The challenge is whether local estimates are available, whether local estimates are unbiased, whether local estimates are synchronized in time, and whether agency-level weights are available for state-level aggregation. This section summarizes these challenges and offers potential solutions to overcome these challenges for the same five relevant subject areas used throughout the report, including survey questions, survey coverage, survey timing, survey unit of analysis, and weighting.

\section{Questions}

The challenge is that not all agencies use both questions in their on-board surveys. Often called the vehicle availability question, only five agencies used the following question for defining choice riders: Do you have a vehicle available that you could have used to make this trip? Of these five, only three also asked the alternative modes question. Furthermore, the vehicle availability question does not qualify that the respondents would have used the available vehicle either as the driver or as a passenger.

Seventeen of the 25 agencies used a broader question in their most recent on-board survey that can be used for estimating captive riders as defined in this report. Often called the "alternative modes question," it includes the response category of "Wouldn't make trip" among other options and typically is stated as follows: How would you make this trip if not by transit? Those who choose "Wouldn't make trip" would be defined as captive riders. Some agencies have tried two alternative practices to measure these markets. In both cases, one single question is used for both markets. It would be great if one single question can be used for defining both markets, but neither of these two alternative practices correctly determines these two markets.

Besides encouragement, one potential solution is to convince agencies of the importance of knowing the size of both of its choice and captive markets. Equally important, however, is to convince agencies that they need both the alternative modes question and the vehicle availability question in order to correctly determine the sizes of these markets. Furthermore, agencies need to realize that the vehicle availability question needs to be more precisely stated to allow both driving and riding as a passenger.

\section{Coverage}

The challenge is incomplete coverage of routes, modes, etc., in the sampling process of local transit on-board surveys. While almost all transit agencies conduct their on-board surveys on a systemwide scale, one agency focused on heavily used routes and another excluded a minor mode in their system in their most recent surveys.

- Besides requiring that a systemwide on-board survey be conducted as part of statutorilyrequired transit development plans, one potential solution is to encourage transit agencies to cover their entire system in designing their on-board surveys. 
- More important, another potential solution is to help transit agencies understand that systemwide coverage does not necessarily mean that they spend more resources on on-board surveys. Systemwide coverage does not mean that data are collected from 100 percent of routes, 100 percent of blocks, 100 percent of runs, and 100 percent of trips. But rather it means that the sampling process covers the entire system. For their most recent on-board surveys, the majority of agencies tried to collect data from 100 percent of their trips during the survey period. They could have collected data only from a statistically valid sample of the 100 percent trips, and used the saved resources to make sure that their sampling process covers the entire system.

\section{Timing}

The challenge is that local transit on-board surveys are not synchronized in time. A few small agencies have never conducted a systemwide transit on-board survey. For those that have conducted some, the most recent on-board survey was conducted as far back as 1997 and as recently as 2006, with the majority since 2002 . Besides the timing of the most recent survey, the interval between two consecutive surveys varies between 1 to 7 years, with 3 to 4 years for most agencies.

- The only potential solution is to use the most recent available on-board surveys every time state-level measurement is desired. One problem with this is that the relative timing of individual surveys may change over time. Another problem is the difficulty in labeling the result of state-level measurement in terms of calendar year because the information from the local agencies is a mix of different years. On the other hand, this may not be as serious a problem. On-board surveys are rarely conducted throughout a year. The Transit Performance Monitoring System tried in its first phase of pilot testing to encourage transit agencies to collect on-board survey data from the year-round sample they use for collecting ridership data for the National Transit Database, but gave up this idea in later phases (McCollom Management Consulting 2004). In addition, a survey conducted during the last days of one year is labeled differently than a survey conducted during the first days of the next year when in fact they are conducted during the same short period.

\section{Unit of Analysis}

One challenge is that the design unit of analysis varies across agencies. A few specifically target riders rather than the boardings they make by asking for one response from any single rider. The vast majority of agencies, however, target the individual boardings that riders make by asking for a response every time the riders board. It would not be reasonable to require the same design unit of analysis be used by all agencies. One solution would be to reflect this difference in agency-level weights for state-level aggregation.

Another challenge is a common conflict in an on-board survey. On one hand, there is the desire for the design unit of analysis of a survey to be the same as the intended unit of analysis for all questions in the survey. On the other hand, a single on-board survey often contains questions that have different intended units of analysis. The intended unit of analysis would be persons for questions on customer satisfaction and socio-demographics, for example. The intended unit of analysis would be linked trips for questions on origin purposes, origin access modes, destination 
purposes, destination egress modes, number of transfers, etc. As discussed earlier, the intended unit of analysis is really round trips for the proposed questions on transit's policy objectives.

One possible but unrealistic solution to this conflict would be not to mix questions with different intended units of analysis in the same on-board survey. Schaller (2005) suggests another potential solution: Ask riders to respond to questions intended for unlinked trips every time they are asked, but ask them to respond to questions intended for persons only the first time they are asked. Another potential solution would be to use different weights for different question types in producing local estimates from raw survey data.

\section{Weighting}

One challenge is that not all agencies weight the raw data from their on-board surveys to correct for potential biases resulting from non-randomness in sampling and in survey administration. Agencies need to be educated that it is a good practice to always weight their raw data in studying their riders even if their sampling process is random.

Another challenge is to find the appropriate weights when agencies do weight their raw data. Research should be carried out to develop a practical guide for agencies. This guide would focus on developing appropriate weights for correcting potential biases at the agency level from the design, sampling, and administration of an on-board survey. Biases may result from survey design when the design unit of analysis differs from the intended unit of analysis for each survey question. Biases may result from sampling when sampling is not random. Biases can also result from nonresponses in survey administration.

A third challenge is to come up with agency-level weights that are consistent across agencies for state-level aggregation. A starting point would be to use agency-level boardings as the weights. When the design unit of analysis varies across agencies and when this design unit of analysis is not boardings, boardings are not appropriate weights for this purpose. The suggested practical guide to be developed should also cover steps for agencies to develop agency-level weights under these circumstances.

\section{Data Transmission}

The challenge is to find a channel for transmitting local estimates to the state. A reasonable approach would be to require all transit agencies to submit a spreadsheet containing the local estimates each time a systemwide on-board survey is completed. The local estimates should be consistent with the final document that reports the results of the on-board survey. A template in Table 6 may be used for this purpose. For measuring the policy objective of providing choices, agencies need to submit the local estimate for the primary question. For measuring basic mobility, however, agencies need to submit the local estimates for only one of the two questions. 
Table 6. Spreadsheet Template for Submitting Local Estimates on Policy Objectives

\begin{tabular}{|c|c|c|c|}
\hline Objectives & Questions & \begin{tabular}{|l|} 
Response \\
Categories
\end{tabular} & $\begin{array}{r}\text { Local } \\
\text { Estimates }\end{array}$ \\
\hline \multirow{3}{*}{ Choice } & \multirow{3}{*}{$\begin{array}{l}\text { Primary Question: Do you have a car or other } \\
\text { personal vehicle that you could have used to } \\
\text { make this trip? }\end{array}$} & Yes & \\
\hline & & No & \\
\hline & & Total & $100 \%$ \\
\hline \multirow{11}{*}{$\begin{array}{l}\text { Basic } \\
\text { Mobility }\end{array}$} & \multirow{3}{*}{$\begin{array}{l}\text { Primary Question: If transit service were not } \\
\text { available, would you have made this trip? }\end{array}$} & Yes & \\
\hline & & No & \\
\hline & & Total & $100 \%$ \\
\hline & \multirow{8}{*}{$\begin{array}{l}\text { Alternative Question: How would you make } \\
\text { this trip if not by transit? }\end{array}$} & Drive & \\
\hline & & Ride with someone & \\
\hline & & Walk & \\
\hline & & Bicycle & \\
\hline & & Taxi & \\
\hline & & Wouldn't make trip & \\
\hline & & \begin{tabular}{|l|} 
Other (specify) \\
\end{tabular} & \\
\hline & & Total & $100 \%$ \\
\hline
\end{tabular}

\section{Conclusions}

Using Florida as a case study, this report has examined the feasibility of using local transit onboard surveys for state-level measurement of states' transit program policy objectives. As part of the transportation system, public transit in Florida helps improve the State's economic competitiveness and quality of life by expanding modal choices to those who do have access to motor vehicles that they could have used to make the trips they currently make by transit (choice riders) and by ensuring basic mobility for people who do not have other options for those trips they make by transit (captive riders). The proposed question for measuring the choice market is: Do you have a vehicle that you would have used to make this trip either as the driver or as a passenger? The proposed question for measuring the captive market is: If transit were not available, would you have made this trip?

There are many challenges. At the local level, they include whether these proposed questions are asked in local surveys, whether local estimates from these two questions are unbiased, and whether local surveys are synchronized in time. At the state level, the challenge is whether appropriate weights are available to aggregate the local estimates to the state level. While there is no simple solution to overcome the lack of synchronization in local estimates, it is not the most serious challenge. In addition, local estimates would be available in the future if an on-board survey were conducted as part of the major updates of statutorily mandated transit development plans and if the proposed questions were part of this survey. The more serious challenges are to come up with appropriate weights both at the sub-agency level for weighting raw survey data to get the local estimates and at the agency level for aggregating the local estimates to the state level. Research should be carried out to develop a practical guide for agencies to develop such weights. 
The state should also benefit from gathering summary data from local transit on-board surveys for state-level measurement on other transportation-related topic areas. These would include trip purposes, access and egress modes, transfers, frequency of transit use, and duration of transit use. The appendix proposes standard questions and response categories for these issues and a spreadsheet template for submitting summary data for these questions.

Before implementing changes in how transit on-board surveys are conducted in the state, it is important to directly dialogue with transit agencies. One efficient channel would be through the Florida Transit Planning Network at the Florida Public Transit Association Conferences.

\section{References}

\section{General}

American Public Transportation Association (2006). Glossary. Accessed on July 12 at 2006http:/www.apta.com/services/safety/glossary.cfm\#c.

Baltes, Michael R. (2002). Customer Surveying for Public Transit: A Design Manual for OnBoard Surveys. National Center for Transit Research, University of South Florida, Tampa, Florida.

Bureau of Transportation Statistics (2004). Survey of State Funding for Public Transportation: 2005. U.S. Department of Transportation, Washington, D.C.

Carr Smith Corradino (2000). South Florida Travel Characteristics Study: Transit On-Board Travel Survey Plan and Findings. Technical Report No. 2.

Cervero, R. (1982). Transit Pricing Evaluation Model: A Tool for Exploring Fare Policy Options. Transportation Research-A 16: 313-323.

Chadda, H.S., and T.E. Mulinazzi (1977). Bus Passenger Surveys in Small Cities. Traffic Quarterly 31: 515-528.

Cochran, William G. (1977). Sampling Techniques, $3^{\text {rd }}$ edition. Wiley, New York.

Cronin, Jr., J. Joseph, and Roscoe Hightower, Jr. (2004). An Evaluation of the Role of Marketing in Public Transit Organizations. Journal of Public Transportation 7: 17-36.

Dean, M.L. (1980). An On-Board, Self-Administered Survey Method for Researching the Mass Transit Rider. Transportation Journal 20: 75-79.

Elmore-Yalch, Rebecca (1998). A Handbook: Integrating Market Research into Transit Management. TCRP Report 37. Transportation Research Board, Washington, D.C.

Guo, Zhan, and Nigel H.M. Wilson (2004). Assessment of the Transfer Penalty for Transit Trips: A GIS-Based Disaggregate Modeling Approach. Transportation Research Record 1872:10-18.

Florida Department of Transportation (2005a). 2025 Florida Transportation Plan. Tallahassee, Florida.

Florida Department of Transportation (2005b). Florida Department of Transportation 2004-2005 Short-Term Component and Annual Performance Report. Tallahassee, Florida.

Florida Department of Transportation (2005c). Florida Transit Information System (FTIS). Tallahassee, Florida.

Florida Department of Transportation (2004). Transit 2020: The Vision. Tallahassee, Florida.

The Florida Senate (2001). Improving Intra-City and Inter-City Mobility. Interim Project Report 2002-151. Tallahassee, Florida. 
Labelle, S.J., and D.G. Stuart (1995). Diverting Automobile Users to Transit: Early Lessons from the Chicago Transit Authority's Orange Line. Transportation Research Record 1503: 79-87.

McCollom Management Consulting (2004). Transit Performance Monitoring System (TPMS) Results: Summary Report, Phase III. American Public Transportation Association, Washington, D.C.

Multisystems, Inc. (1985). Transit Data Collection Design Manual. U.S. Department of Transportation, Washington, D.C.

Office of Program Policy Analysis and Government Accountability (1999). Public Transportation Program Meets Most Standards; Accountability System in Need of Strengthening. PB ${ }^{2}$

Performance Report No. 98-55. The Florida Legislature, Tallahassee, Florida.

O’Sullivan, Sean, and John Morrall (1996). Walking Distances to and from Light-Rail Transit Stations. Transportation Research Record 1538: 19-26.

Polzin, Steven E., and Xuehao Chu (2005). A Closer Look at Public Transportation Mode Share Trends. Journal of Transportation and Statistics 8: 1-13.

Potts, John F. (2002). Customer-Focused Transit. TCRP Synthesis 45. Transportation Research Board, Washington, D.C.

Retzlaff, J., K. Soucie, and E. Beimborn (1985). A Guide to the Use of Market Research in Public Transit. UMTA-WI-11-0009-85-1. Center for Urban Transportation Studies, University of Wisconsin, Milwaukee.

Richardson, A.J., Harbutt, P.L., and Lester C. (1998). "Public Transport Ticket Usage Surveys A Methodological Design." Forum Papers $-22^{\text {nd }}$ Australian Transport Research Forum, Sydney, Volume 2, pp. 697-712.

Schaller, Bruce (2005). On-Board and Intercept Transit Survey Techniques: A Synthesis of Transit Practice. TCRP Synthesis 65. Transportation Research Board, Washington, D.C.

Sheskin, I.M. and P.R. Stopher (1982). "Pilot Testing of Alternative Administrative Procedures and Survey Instruments," Transportation Research Record 886: 8-22

Teal, Roger F., and Terry Nemer (1986). Privatization of Urban Transit: The Los Angeles Jitney Experience. Transportation 13: 5-22.

Thakuriah, Piyushimita, P.S. Sriraj, Siim Soot, Yihua Liao, and Gidon Berman (2005). Activity and Travel Changes of Job Access Transportation Service Users: An Analysis of a User Survey. Transportation 2005 Annual Meeting CD-ROM.

U.S. Department of Transportation (2002). 2002 Status of the Nation's Highways, Bridge, and Transit: Conditions and Performance. Washington, D.C.

\section{On-Board Surveys}

CUTR (2005). Bay County Transit Development Plan 2006-2010: Final Report. University of South Florida, Tampa, Florida.

Renaissance Planning Group (2005). Space Coast Area Transit 2004 Rider Survey. Tampa, Florida.

Parsons Brinckerhoff Corporation (2003). Broward County Transit Development Plan FY2005FY2009: December 2004-Major Update.

CUTR (2005). Collier County Transit Development Plan: Major Update-2006-2015. University of South Florida, Tampa, Florida.

CUTR (2005). Escambia County Five-Year Transit Development Plan 2006-2010: Final Report. University of South Florida, Tampa, Florida. 
Perteet Engineering (2002). Gainesville Regional Transit System Comprehensive Operational Analysis. Everett, Washington.

Tindale-Oliver and Associates (2003). Hernando County MPO 2003 Transit Operations Plan. Tampa, Florida

Clark, Hugh M. (2001). Hillsborough Area Regional Transit Authority 2001 March Research Study: An Onboard Survey of HARTline Riders. Columbus, $\mathrm{OH}$

Tindale-Oliver and Associates (2005a). Indian River County MPO Transit Development Plan. Tampa, Florida.

JTA (2004). JTA Transit Development Plan FY2005-FY2009. Jacksonville, Florida.

CUTR (2000). Key West Transit Development Plan: Draft Report. University of South Florida, Tampa, Florida.

Polk Transportation Planning Organization (1998). Executive Summary of the 1997 Citrus Connection User Survey of the Lakeland Area Mass Transit District. Bartow, Florida.

CUTR (2003). Lee County Five-Year Transit Development Plan 2004-2008 and 2009-2013. University of South Florida, Tampa, Florida.

Glatting Jackson Kercher Anglin Lopez Rinehart, Inc. (2001). 2001 LYNX Market Research Study. Orlando, Florida.

CUTR (2004). Manatee County Area Transit: Transit Development Plan 2005-2009. University of South Florida, Tampa, Florida.

Martin County MPO (2004). Martin County Transit Development Plan 2005-2014. Stuart, Florida.

Behavioral Science Research Corporation (2004). An Assessment of the Ridership Patterns of Miami-Dade County Metrobus Riders. Coral Gables, Florida.

Behavioral Science Research Corporation (2005). An Assessment of the Ridership Patterns of Miami-Dade County Metrorail Riders. Coral Gables, Florida.

CUTR (2005). Okaloosa/Walton Transportation Planning Organization Transit Development Plan 2006-2010: Final Report. University of South Florida, Tampa, Florida.

CUTR (2003). Palm Beach County Transit Development Plan 2004-2008. University of South Florida, Tampa, Florida.

Tindale-Oliver and Associates (2005b). Pasco County Transit Development Plan 2006-2010. Tampa, Florida.

CB\&A Research Inc. (2004). Pinellas Suncoast Transit Authority Spring 2004 On-Board Survey: Report of Findings. Winston-Salem, North Carolina

CUTR (2002). Sarasota County Transit Development Plan 2003-2007. University of South Florida, Tampa, Florida.

CUTR (2005). Tallahassee Transit Development Plan. University of South Florida, Tampa, Florida.

South Florida Regional Transportation Authority (2005). Tri-Rail Development Plan. Pompano Beach, Florida

CUTR (2002). Volusia County Transit Development Plan 2003-2007. University of South Florida, Tampa, Florida. 


\section{Appendix: Other Topics}

Three other topic areas commonly covered in transit on-board surveys may be of interest to the State. These topics include trip purposes, access and egress, and transit usage. This appendix addresses three aspects of these topics: the current practice of asking the related questions, proposed standards on how these questions may be asked, and a proposed spreadsheet template for agencies to submit their summary data to the State.

\section{Current Practice}

The current practice of on-board surveys regarding these topic areas is summarized from three aspects: coverage, questions, and response categories. Coverage refers to whether and how each topic area is included in an on-board survey. Questions refer to how each topic area is formulated into on-board survey questions. Response categories refer to the listed multiple choices available for respondents to choose from in answering an on-board question.

Coverage. Table 7 summarizes the coverage of these topic areas in the most recently documented on-board surveys in Florida. The following are some highlights:

- All agencies cover trip purposes in their most recent on-board surveys. About two-thirds of them ask for both origin and destination purposes, but the rest ask for the overall purpose of a trip using this question: "What is the primary purpose of this trip?" There are a few exceptions. Brevard County Transit covers origin purposes but not destination purposes, and Manatee County Transit asks for both the overall purpose of a trip as well as the origin and destination purposes.

- Among these 25 agencies reviewed, 22 cover access modes, 20 cover egress modes, and 12 cover transfers in separate questions. When access/egress modes are covered, both access and egress modes are covered in most cases. Exceptions include covering only egress but not access modes (Broward County Transit) and covering only access but not egress modes (Indian River County Transit, Pasco County Transit, and Pinellas County Transit).

- Whether and how transfers are covered varies significantly across the agencies. A total of 21 agencies cover transfers. Nine cover transfers through their questions on access/egress modes, eight cover them through a separate question, and four cover both through their questions on access/egress modes and through a separate question.

- Transit usage is represented by both frequency (e.g., use transit 5 days a week) and duration (e.g., 6 months, 1 year, etc.). Among the 25 agencies, 16 cover both frequency and duration, 6 covers frequency only, 2 cover duration only, and 1 does not cover either frequency or duration. 
Table 7. Coverage of Other Topic Areas

\begin{tabular}{|l|c|c|c|c|c|c|c|c|}
\hline \multirow{2}{*}{ Agencies } & \multicolumn{3}{|c|}{ Purpose } & \multicolumn{3}{c|}{ Access/Egress } & \multicolumn{3}{c|}{ Usage } \\
\cline { 2 - 9 } & Origin & Destination & Overall & $\begin{array}{c}\text { Access } \\
\text { Modes }\end{array}$ & $\begin{array}{c}\text { Egress } \\
\text { Modes }\end{array}$ & Transfer & Frequency & Duration \\
\hline Bay County Trolley & 1 & 1 & 0 & 1 & 1 & 1 & 1 & 1 \\
\hline Brevard County Transit & 1 & 0 & 1 & 2 & 2 & 0 & 1 & 1 \\
\hline Broward County Transit & 0 & 0 & 1 & 0 & 2 & 0 & 1 & 0 \\
\hline Collier County Transit & 1 & 1 & 0 & 2 & 2 & 0 & 1 & 0 \\
\hline Escambia County Transit & 1 & 1 & 0 & 1 & 1 & 1 & 1 & 1 \\
\hline Gainesville Transit & 1 & 1 & 0 & 2 & 2 & 1 & 0 & 1 \\
\hline Hernando County Transit & 1 & 1 & 0 & 1 & 1 & 0 & 1 & 0 \\
\hline Hillsborough County Transit & 0 & 0 & 1 & 0 & 0 & 1 & 1 & 0 \\
\hline Indian River County Transit & 0 & 0 & 1 & 1 & 0 & 0 & 1 & 0 \\
\hline Jacksonville Transit (bus) & 0 & 0 & 1 & 2 & 2 & 1 & 1 & 1 \\
\hline Jacksonville Transit (skyway) & 1 & 1 & 0 & 2 & 2 & 1 & 1 & 1 \\
\hline Key West Transit & 1 & 1 & 0 & 2 & 1 & 1 & 1 & 1 \\
\hline Lakeland Transit & 1 & 1 & 0 & 1 & 1 & 0 & 0 & 0 \\
\hline Lee County Transit & 1 & 1 & 0 & 1 & 1 & 1 & 1 & 1 \\
\hline Lynx & 1 & 1 & 0 & 2 & 2 & 0 & 1 & 0 \\
\hline Manatee County Transit & 1 & 1 & 1 & 2 & 2 & 1 & 1 & 1 \\
\hline Martin County Transit (Connector) & 0 & 0 & 1 & 0 & 0 & 0 & 1 & 1 \\
\hline Miami-Dade County Transit (Bus) & 1 & 1 & 0 & 2 & 2 & 0 & 1 & 1 \\
\hline Miami-Dade County Transit (Rail) & 1 & 1 & 0 & 2 & 2 & 0 & 1 & 0 \\
\hline Okaloosa County Transit & 1 & 1 & 0 & 1 & 1 & 1 & 1 & 1 \\
\hline Palm Beach County Transit & 0 & 0 & 1 & 1 & 1 & 1 & 1 & 1 \\
\hline Pasco County Transit & 0 & 0 & 1 & 1 & 0 & 0 & 0 & 1 \\
\hline Pinellas County Transit & 0 & 0 & 1 & 1 & 0 & 1 & 1 & 1 \\
\hline Sarasota County Transit & 1 & 1 & 0 & 2 & 2 & 0 & 1 & 1 \\
\hline Tallahassee Transit & 1 & 1 & 0 & 2 & 2 & 0 & 1 & 1 \\
\hline Tri-Rail & 1 & 1 & 0 & 2 & 2 & 0 & 1 & 1 \\
\hline Volusia County Transit & 1 & 1 & 0 & 1 & 1 & 1 & 1 & 1 \\
\hline Total Agency/Mode & 19 & 18 & 10 & 24 & 22 & 13 & 24 & 19 \\
\hline Total Agency & 18 & 17 & 10 & 22 & 20 & 12 & 22 & 18 \\
\hline
\end{tabular}

Notes: $0=$ not covered; $1=$ covered; and $2=$ transferring is one of the access/egress modes.

Questions. Table 8 lists the typically worded questions for each topic area (Q1-Q8) and some of the variations in how the questions are formed (V01-V37). There is little variation in how the questions are asked on destination purposes and duration of transit use. There are significant variations, however, in how the questions are asked on the other topic areas. Some of these variations are minor wording differences that do not necessarily lead to significant problems for respondents and for data interpretation. Examples are some of the variations in the questions on the general purpose of a trip: V03, V07, V09, and V11. Other variations are more significant than just wording differences. The following are some of these:

- Some variations are general rather than specific to the subject trip. These occur to the topic areas on general purposes and access modes. Related to general purposes (Q3), examples 
of variations being general rather than being specific to the trip made include V04, V06, and V10. Related to access modes (Q4), examples of variations being general include V13 and V16.

- Some variations result from whether the information being collected is intended for linked or unlinked trips. As typically formed, the question on access modes (Q4) is vague in its intension. Some of the variations to Q4 try to be clearer. It is clear, for example, that V17 is intended for unlinked trips. Similarly, the question on egress modes (Q5) also is vague, but some of its variations try to be clearer. It is clear that V18 and V19 are intended for unlinked trips, but that V21 is intended for linked trips.

- Some variations result from the need to get more information than the typically formed question. One example would be those related to transfers (Q6). When covered, most agencies focus on whether transfers are required for completing a linked trip, including the typically worded question and most of its variations. But V31 is intended to collect the total number of transfers for any linked trip. 
Table 8. Variations in Questions

\begin{tabular}{|c|c|c|}
\hline & Typical Wording & Variations \\
\hline \multirow{3}{*}{ 气ू } & $\begin{array}{l}\text { Origin Purpose: (Q1) } \\
\text { Where did you come } \\
\text { from before you got } \\
\text { on the bus for this } \\
\text { trip? }\end{array}$ & $\begin{array}{l}\text { (V01) Where did you start this trip today? } \\
\text { (V02) Where were you when you started this trip today? }\end{array}$ \\
\hline & $\begin{array}{l}\text { Destination Purpose: } \\
\text { (Q2) Where are you } \\
\text { going on this trip? }\end{array}$ & No variations \\
\hline & $\begin{array}{l}\text { General: }(\mathrm{Q} 3) \text { What } \\
\text { is the primary } \\
\text { purpose of this trip? }\end{array}$ & $\begin{array}{l}\text { (V03) What is the one main purpose of this trip you are making right now? } \\
\text { (V04) What do you normally use the service for? } \\
\text { (V05) What is the purpose of the trip you are currently taking? } \\
\text { (V06) For what trip purpose do you use MCAT? } \\
\text { (V07) What is your primary purpose for today's trip? } \\
\text { (V08) What is your destination for this trip? } \\
\text { (V09) What is the primary purpose of your trip? } \\
\text { (V10) What do you normally use the bus for? } \\
\text { (V11) What is the purpose of this trip? }\end{array}$ \\
\hline \multirow{3}{*}{ 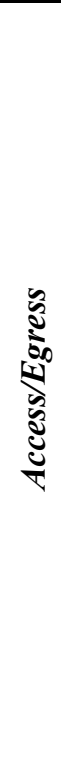 } & $\begin{array}{l}\text { Access: (Q4) How } \\
\text { did you get to the } \\
\text { stop for this trip? }\end{array}$ & $\begin{array}{l}\text { (V12) How did you get to the bus stop for this particular bus trip? } \\
\text { (V13) How do you usually get to the bus? } \\
\text { (V14) How did you get to this bus? } \\
\text { (V15) How did you get to the Metrorail station where you started this trip? } \\
\text { (V16) How do you usually get to the bus stop? } \\
\text { (V17) How did you arrive at the station where you boarded the train? }\end{array}$ \\
\hline & $\begin{array}{l}\text { Egress: (Q5) How } \\
\text { will you get to your } \\
\text { final destination? }\end{array}$ & $\begin{array}{l}\text { (V18) What will you do when you get off this bus? } \\
\text { (V19) How will you continue your trip after riding this bus? } \\
\text { (V20) How will you get to your final destination at the end of this trip? } \\
\text { (V21) After you finish your bus travel, how will you get to your final destination? } \\
\text { (V22) How do you reach your final destination once you depart the bus? } \\
\text { (V23) How will you get to your final destination? } \\
\text { (V24) How will you get to the end of this trip? }\end{array}$ \\
\hline & $\begin{array}{l}\text { Transfers: (Q6) Do } \\
\text { you need to transfer } \\
\text { to complete this trip }\end{array}$ & $\begin{array}{l}\text { (V25) Does your current trip involve a transfer? } \\
\text { (V26) Will you transfer to another bus to complete this trip? } \\
\text { (V27) Do you have to transfer to another bus to get where you are going on this trip? } \\
\text { (V28) Will you transfer at Central Station to complete your SKYWAY trip? } \\
\text { (V29) Does this trip involve a transfer? } \\
\text { (V30) How many buses will you need to complete this trip? }\end{array}$ \\
\hline \multirow[t]{2}{*}{$\frac{1}{8}$} & $\begin{array}{l}\text { Frequency: (Q7) } \\
\text { How often do you } \\
\text { ride the bus? }\end{array}$ & $\begin{array}{l}\text { (V31) How many days a week do you usually make this trip? } \\
\text { (V32) How many days a week do you usually ride the bus? } \\
\text { (V33) How many one-way bus trips do you make in a typical week? } \\
\text { (V34) How often do you use a transit bus? } \\
\text { (V35) How frequently do you ride XXX? } \\
\text { (V36) How many trips do you make per week using public transportation? } \\
\text { (V37) In the past seven days, how may days have you ridden a bus (including today)? }\end{array}$ \\
\hline & $\begin{array}{l}\text { Duration: (Q8) How } \\
\text { long have you been } \\
\text { using transit? }\end{array}$ & No variations \\
\hline
\end{tabular}




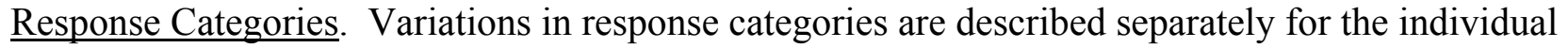
topic areas.

- Among the 18 agencies that cover trip purposes, there are 14 different patterns of response categories as shown in the columns of Table 9. Those patterns with "Home" $(\mathrm{H})$ as one of the categories are for the questions on origin or destination purposes, while those patterns without "Home" are for the questions on general purposes. All 14 patterns include "Work" as a category. Almost all include "School" (L) and "Medical" (M) as separate categories. Five patterns separate "College" (C) from other schools. All 14 patterns include shopping, with 10 treating it as a separate purpose $(\mathrm{P})$ but the other 4 combine it with errands $(\mathrm{P}+\mathrm{E})$.

Table 9. Variations in Response Categories on Trip Purposes

\begin{tabular}{|c|c|c|c|c|c|c|c|c|c|c|c|c|c|}
\hline $\mathbf{1}$ & $\mathbf{2}$ & $\mathbf{3}$ & $\mathbf{4}$ & $\mathbf{5}$ & $\mathbf{6}$ & $\mathbf{7}$ & $\boldsymbol{8}$ & $\mathbf{9}$ & $\mathbf{1 0}$ & $\mathbf{1 1}$ & $\mathbf{1 2}$ & $\mathbf{1 3}$ & $\mathbf{1 4}$ \\
\hline $\mathrm{H}$ & $\mathrm{H}$ & $\mathrm{H}$ & $\mathrm{H}$ & & $\mathrm{H}$ & & $\mathrm{H}$ & $\mathrm{H}$ & $\mathrm{H}$ & $\mathrm{H}$ & $\mathrm{H}$ & & $\mathrm{H}$ \\
\hline $\mathrm{W}$ & $\mathrm{W}$ & $\mathrm{W}$ & $\mathrm{W}$ & $\mathrm{W}$ & $\mathrm{W}$ & $\mathrm{W}$ & $\mathrm{W}$ & $\mathrm{W}$ & $\mathrm{W}$ & $\mathrm{W}$ & $\mathrm{W}$ & $\mathrm{W}$ & $\mathrm{W}$ \\
\hline & & & & & & & & & & & & & $\mathrm{BE}$ \\
\hline $\mathrm{L}$ & $\mathrm{L}$ & $\mathrm{L}$ & & $\mathrm{L}$ & $\mathrm{L}$ & $\mathrm{L}$ & $\mathrm{L}$ & $\mathrm{L}$ & $\mathrm{L}$ & $\mathrm{L}$ & $\mathrm{L}$ & $\mathrm{L}$ & $\mathrm{L}$ \\
\hline $\mathrm{C}$ & $\mathrm{C}$ & & & & $\mathrm{C}$ & $\mathrm{C}$ & $\mathrm{C}$ & & & & & & \\
\hline $\mathrm{M}$ & $\mathrm{M}$ & $\mathrm{M}$ & $\mathrm{M}$ & $\mathrm{M}$ & $\mathrm{M}$ & $\mathrm{M}$ & $\mathrm{M}$ & $\mathrm{M}$ & $\mathrm{M}$ & $\mathrm{M}$ & $\mathrm{M}$ & $\mathrm{M}$ & \\
\hline $\mathrm{P}+\mathrm{E}$ & $\mathrm{P}+\mathrm{E}$ & $\mathrm{P}+\mathrm{E}$ & $\mathrm{P}+\mathrm{E}$ & & & & & & & & & & \\
\hline & & & & $\mathrm{P}$ & $\mathrm{P}$ & $\mathrm{P}$ & $\mathrm{P}$ & $\mathrm{P}$ & $\mathrm{P}$ & $\mathrm{P}$ & $\mathrm{P}$ & $\mathrm{P}$ & $\mathrm{P}$ \\
\hline & & & & & $\mathrm{PB}$ & & & & & & & & \\
\hline & & & & & & & & & & & & & $\mathrm{PE}$ \\
\hline $\mathrm{V}+\mathrm{R}$ & $\mathrm{V}+\mathrm{R}$ & $\mathrm{V}+\mathrm{R}$ & $\mathrm{V}+\mathrm{R}$ & & & & & & & $\mathrm{V}+\mathrm{R}$ & & & \\
\hline & & & & $\mathrm{V}$ & & & & & & & & & \\
\hline & & & & & & $\mathrm{SV}$ & & & & & & $\mathrm{SV}$ & \\
\hline & & & & & & $\mathrm{SS}$ & & & & & & & \\
\hline & & & & & & & & $\mathrm{S}+\mathrm{R}$ & $\mathrm{S}+\mathrm{R}$ & & & & \\
\hline $\mathrm{U}$ & & & & & & & & & & & & & \\
\hline & & & & & & & $\mathrm{R}$ & & & & $\mathrm{R}$ & & \\
\hline & & & & & & & $\mathrm{A}$ & & & & & & \\
\hline $\mathrm{O}$ & $\mathrm{O}$ & $\mathrm{O}$ & $\mathrm{O}$ & $\mathrm{O}$ & $\mathrm{O}$ & $\mathrm{O}$ & & & $\mathrm{O}$ & $\mathrm{O}$ & $\mathrm{O}$ & $\mathrm{O}$ & $\mathrm{O}$ \\
\hline
\end{tabular}

Notes:

$\begin{array}{lll}\mathrm{A}=\text { Airport } & \mathrm{O}=\text { Other } & \mathrm{W}=\text { Work } \\ \mathrm{C}=\text { College } & \mathrm{P}=\text { Shopping } & \mathrm{BE}=\text { Business Errands } \\ \mathrm{E}=\text { Errands } & \mathrm{R}=\text { Recreation } & \mathrm{PB}=\text { Personal Business } \\ \mathrm{H}=\text { Home } & \mathrm{S}=\text { Social } & \mathrm{PE}=\text { Personal Errands } \\ \mathrm{L}=\text { School } & \mathrm{U}=\text { Church } & \mathrm{SS}=\text { Social Service } \\ \mathrm{M}=\text { Medical } / \text { dental } & \mathrm{V}=\text { Visiting } & \mathrm{SV}=\text { Social Visiting }\end{array}$

- The response categories for the topic areas of access and egress are identical in the particular modes included. These modes are walking, driving, riding in a passenger vehicle as a passenger (being dropped off for access but being picked up for egress), biking, and other modes. But they differ in two aspects. One relates to whether transferring is an access or egress mode. The particular approach taken by individual agencies on this was discussed earlier about the coverage of topic areas. The other relates to whether and how walking is further disaggregated by walking distance (Table 10). Among the 22 agencies covering access and egress, there are 8 different patterns of response categories on walking. Four agencies do not disaggregate walking by distance. Nine agencies use "walking 3 
blocks or less" and "walking more than 3 blocks." Two patterns relate distance in miles, while the other patterns relate distance in blocks.

Table 10. Variations in Walk-Related Response Categories on Access/Egress

\begin{tabular}{|c|c|c|c|c|c|c|c|c|}
\hline \multirow{2}{*}{$\begin{array}{c}\text { Patterns } \\
\text { (unit) }\end{array}$} & \multicolumn{8}{|c|}{ Number of Agencies } \\
\hline & 4 & 9 & 3 & 1 & 1 & 2 & 1 & 1 \\
\hline $\begin{array}{c}1 \\
\text { (blocks) } \\
\end{array}$ & Walk & & & & & & & \\
\hline $\begin{array}{c}2 \\
\text { (blocks) }\end{array}$ & & $\begin{array}{l}\text { Walk 0-3 } \\
\text { Walk 3+ }\end{array}$ & & & & & & \\
\hline $\begin{array}{c}3 \\
\text { (blocks) }\end{array}$ & & & $\begin{array}{c}\text { Walk } 1 \\
\text { Walk } 2 \\
\text { Walk } 3 \\
\text { Walk 4+ }\end{array}$ & & & & & \\
\hline $\begin{array}{c}4 \\
\text { (blocks) }\end{array}$ & & & & $\begin{array}{l}\text { Walk 1- } \\
\text { Walk 1-2 } \\
\text { Walk 3-4 } \\
\text { Walk 5+ }\end{array}$ & & & & \\
\hline $\begin{array}{c}5 \\
\text { (blocks) }\end{array}$ & & & & & $\begin{array}{l}\text { Walk 1- } \\
\text { Walk 1-2 } \\
\text { Walk 2-5 } \\
\text { Walk 5+ } \\
\end{array}$ & & & \\
\hline $\begin{array}{c}6 \\
\text { (blocks) }\end{array}$ & & & & & & $\begin{array}{c}\text { Walk 1 } \\
\text { Walk 2-4 } \\
\text { Walk 5+ }\end{array}$ & & \\
\hline $\begin{array}{c}7 \\
\text { (miles) }\end{array}$ & & & & & & & $\begin{array}{c}\text { Walk 1/8 } \\
\text { Walk 1/8/-1/4 } \\
\text { Walk } 1 / 4+\end{array}$ & \\
\hline $\begin{array}{c}8 \\
\text { (miles) }\end{array}$ & & & & & & & & $\begin{array}{c}\text { Walk } 1 / 4- \\
\text { Walk } 1 / 4+\end{array}$ \\
\hline
\end{tabular}

- As discussed earlier on the coverage of topic areas, one agency solicits the total number of transfers, but all other agencies just ask a yes-or-no question about transferring in a separate question. As a result, there are no variations for each question type.

- A total of 22 agencies cover frequency of transit usage in their most recent on-board surveys, and there are 22 different patterns of transit usage (Table 11).

- Among the 18 agencies covering duration of transit usage, there are 9 different patterns of response categories (Table 12). 
Table 11. Variations in Response Categories on Frequency of Transit Usage

\begin{tabular}{|c|c|c|c|c|c|c|c|c|c|c|c|c|c|c|c|c|c|c|c|c|c|}
\hline 1 & 2 & 3 & 4 & 5 & 6 & 7 & 8 & 9 & 10 & 11 & 12 & 13 & 14 & 15 & 16 & 17 & 18 & 19 & 20 & 21 & 22 \\
\hline & & $\mathrm{E}$ & & & & & & & & & & & $\mathrm{E}$ & & & & & & & & \\
\hline & & & & & $7 \mathrm{~d} / \mathrm{w}$ & & $7 \mathrm{~d} / \mathrm{w}$ & & & $7 \mathrm{~d} / \mathrm{w}$ & & & & & & & & & & $7 \mathrm{~d} / \mathrm{w}$ & $7 \mathrm{~d} / \mathrm{w}$ \\
\hline & & & & & & & & & & & & & & & & & $6-7 \mathrm{~d} / \mathrm{w}$ & & & & \\
\hline & & & $6 \mathrm{~d} / \mathrm{w}$ & & $6 \mathrm{~d} / \mathrm{w}$ & & $6 \mathrm{~d} / \mathrm{w}$ & $6 \mathrm{~d} / \mathrm{w}$ & & $6 \mathrm{~d} / \mathrm{w}$ & & & & & & & & & $6 \mathrm{~d} / \mathrm{w}$ & $6 \mathrm{~d} / \mathrm{w}$ & $6 \mathrm{~d} / \mathrm{w}$ \\
\hline & & & & & & & & & & & $5-7 \mathrm{~d} / \mathrm{w}$ & & & $5-7 \mathrm{~d} / \mathrm{w}$ & $5-7 \mathrm{~d} / \mathrm{w}$ & & & & & & \\
\hline & & & & & & & & & & & & & & & & & & $5 \mathrm{~d}+/ \mathrm{w}$ & & & \\
\hline \multirow[t]{4}{*}{$5 \mathrm{~d} / \mathrm{w}$} & & & $5 \mathrm{~d} / \mathrm{w}$ & $5 \mathrm{~d} / \mathrm{w}$ & $5 \mathrm{~d} / \mathrm{w}$ & & $5 \mathrm{~d} / \mathrm{w}$ & & $5 \mathrm{~d} / \mathrm{w}$ & $5 \mathrm{~d} / \mathrm{w}$ & & & & & & & & $5 \mathrm{~d} / \mathrm{w}$ & $5 \mathrm{~d} / \mathrm{w}$ & $5 \mathrm{~d} / \mathrm{w}$ & $5 \mathrm{~d} / \mathrm{w}$ \\
\hline & & & & & & & & & & & & & & & & & & $5 \mathrm{~d}-/ \mathrm{w}$ & & & \\
\hline & $4 \mathrm{~d}+/ \mathrm{w}$ & & & & & $4 \mathrm{~d}+/ \mathrm{w}$ & & & & & & $4 \mathrm{~d}+/ \mathrm{w}$ & & & & $4 \mathrm{~d}+/ \mathrm{w}$ & & & & & \\
\hline & & $4-5 \mathrm{~d} / \mathrm{w}$ & & & & & & $4-5 \mathrm{~d} / \mathrm{w}$ & & & & & & & & & $4-5 \mathrm{~d} / \mathrm{w}$ & & & & \\
\hline \multirow[t]{2}{*}{$4 \mathrm{~d} / \mathrm{w}$} & & & $4 \mathrm{~d} / \mathrm{w}$ & & $4 \mathrm{~d} / \mathrm{w}$ & & $4 \mathrm{~d} / \mathrm{w}$ & & $4 \mathrm{~d} / \mathrm{w}$ & $4 \mathrm{~d} / \mathrm{w}$ & & & & & & & & & $4 \mathrm{~d} / \mathrm{w}$ & $4 \mathrm{~d} / \mathrm{w}$ & $4 \mathrm{~d} / \mathrm{w}$ \\
\hline & & & & $3-4 \mathrm{~d} / \mathrm{w}$ & & & & & & & & & & $3-4 \mathrm{~d} / \mathrm{w}$ & $3-4 \mathrm{~d} / \mathrm{w}$ & & & & & & \\
\hline \multirow[t]{3}{*}{$3 \mathrm{~d} / \mathrm{w}$} & & & $3 \mathrm{~d} / \mathrm{w}$ & & $3 \mathrm{~d} / \mathrm{w}$ & & $3 \mathrm{~d} / \mathrm{w}$ & & $3 \mathrm{~d} / \mathrm{w}$ & $3 \mathrm{~d} / \mathrm{w}$ & & & & & & & & & $3 \mathrm{~d} / \mathrm{w}$ & $3 \mathrm{~d} / \mathrm{w}$ & $3 \mathrm{~d} / \mathrm{w}$ \\
\hline & & & & & & & & & & & $2-4 \mathrm{~d} / \mathrm{w}$ & & & & & & & & & & \\
\hline & & $2-3 \mathrm{~d} / \mathrm{w}$ & & & & $2-3 \mathrm{~d} / \mathrm{w}$ & & $2-3 \mathrm{~d} / \mathrm{w}$ & & & & $2-3 \mathrm{~d} / \mathrm{w}$ & & & & $2-3 \mathrm{~d} / \mathrm{w}$ & $2-3 \mathrm{~d} / \mathrm{w}$ & & & & \\
\hline \multirow[t]{3}{*}{$2 \mathrm{~d} / \mathrm{w}$} & & & $2 \mathrm{~d} / \mathrm{w}$ & & $2 \mathrm{~d} / \mathrm{w}$ & & $2 \mathrm{~d} / \mathrm{w}$ & & & $2 \mathrm{~d} / \mathrm{w}$ & & & & & & & & & & & $2 \mathrm{~d} / \mathrm{w}$ \\
\hline & $1-3 \mathrm{~d} / \mathrm{w}$ & & & & & & & & & & & & & & & & & & & & \\
\hline & & & & $1-2 \mathrm{~d} / \mathrm{w}$ & & & & & $1-2 \mathrm{~d} / \mathrm{w}$ & & & & & $1-2 \mathrm{~d} / \mathrm{w}$ & $1-2 \mathrm{~d} / \mathrm{w}$ & & & & $1-2 \mathrm{~d} / \mathrm{w}$ & $1-2 \mathrm{~d} / \mathrm{w}$ & \\
\hline \multirow[t]{7}{*}{$1 \mathrm{~d} / \mathrm{w}$} & & $1 \mathrm{~d} / \mathrm{w}$ & $1 \mathrm{~d} / \mathrm{w}$ & & $1 \mathrm{~d} / \mathrm{w}$ & $1 \mathrm{~d} / \mathrm{w}$ & $1 \mathrm{~d} / \mathrm{w}$ & $1 \mathrm{~d} / \mathrm{w}$ & & $1 \mathrm{~d} / \mathrm{w}$ & & $1 \mathrm{~d} / \mathrm{w}$ & & & & $1 \mathrm{~d} / \mathrm{w}$ & $1 \mathrm{~d} / \mathrm{w}$ & & & & $1 \mathrm{~d} / \mathrm{w}$ \\
\hline & & & & & & & $0 \mathrm{~d} / \mathrm{w}$ & & & & & & & & & & & & & & \\
\hline & & & & & & & & & & & & & $2-4 \mathrm{t} / \mathrm{w}$ & & & & & & & & \\
\hline & & & & & & & & & & & $1 \mathrm{t} / \mathrm{w}$ & & $1 \mathrm{t} / \mathrm{w}$ & & & & & & & & \\
\hline & & & & & & & & & & & & & & $1 \mathrm{t}-/ \mathrm{w}$ & $1 \mathrm{t}-/ \mathrm{w}$ & $1 \mathrm{t}-/ \mathrm{w}$ & & & & & \\
\hline & G & & & & & & & & & & & G & $\mathrm{G}$ & & & & & & $\mathrm{G}$ & $\mathrm{G}$ & \\
\hline & & & $2-3 \mathrm{t} / \mathrm{m}$ & & & & & & & $2-3 \mathrm{t} / \mathrm{m}$ & & & & & & & & & & & \\
\hline \multirow[t]{4}{*}{$1-3 \mathrm{t} / \mathrm{m}$} & & & & & & & & & $1-3 \mathrm{t} / \mathrm{m}$ & & & & & & & & & & & & \\
\hline & & & & & & & & & & & $1-2 \mathrm{t} / \mathrm{m}$ & & & & & & $1-2 \mathrm{t} / \mathrm{m}$ & & & & \\
\hline & $1 \mathrm{t}-/ \mathrm{m}$ & $1 \mathrm{t}-/ \mathrm{m}$ & & & & $1 \mathrm{t}-/ \mathrm{m}$ & & & & & $1 \mathrm{t}-/ \mathrm{m}$ & & & & & & $1 \mathrm{t}-/ \mathrm{m}$ & & $1 \mathrm{t}-/ \mathrm{m}$ & $1 \mathrm{t}-/ \mathrm{m}$ & $1 \mathrm{t}-/ \mathrm{m}$ \\
\hline & & & & $\mathrm{O}$ & & & & & & & & & $\mathrm{O}$ & & & & & & & & \\
\hline \multirow[t]{2}{*}{$1 \mathrm{st} \mathrm{t}$} & & & & $1 \mathrm{st} \mathrm{t}$ & & & & & & & & & & & $1 \mathrm{st} \mathrm{t}$ & & & & & & $1 \mathrm{st} \mathrm{t}$ \\
\hline & & & & & & $\mathrm{N}$ & & & & & & & & & & & & & & & \\
\hline $\mathrm{V}$ & & & & & & & & $\mathrm{V}$ & $\mathrm{V}$ & & & & & & & & & & & & \\
\hline
\end{tabular}

\section{Notes:}

$\mathrm{E}=$ Everyday $\quad \mathrm{F}=1$ time every a few weeks

$\mathrm{d}=$ day or days $\quad \mathrm{t}=$ time or times
$\mathrm{G}=\mathrm{A}$ few times per month

$1 \mathrm{t}$ - = less than 1 time
$\mathrm{N}=$ Never

$/ \mathrm{m}=$ per month
$\mathrm{O}=$ Occasionally

$\mathrm{V}=$ Visitor/touris

$\mathrm{w}=$ per week 
Table 12. Variations in Response Categories for Duration

\begin{tabular}{|c|c|c|c|c|c|c|c|c|}
\hline 1 & 2 & 3 & 4 & 5 & 6 & 7 & 8 & 9 \\
\hline & & & $1^{\text {st }}$ time & & & & & $1^{\text {st }}$ time \\
\hline $1^{\text {st }}$ day & $1^{\text {st }}$ day & & & & & $1^{\text {st }}$ day & & \\
\hline \multicolumn{9}{|l|}{1 month- } \\
\hline & & & & & & 3 months- & & \\
\hline & & & & & & 3-6 months & & \\
\hline \multicolumn{9}{|l|}{$1-6$ months } \\
\hline & 6 months- & & 6 months- & 6 months- & 6 months- & & & \\
\hline & & & $.5-1$ year & $.5-1$ year & $.5-1$ year & & & \\
\hline & $.5-2$ years- & & & & & & & \\
\hline \multirow[t]{6}{*}{$\begin{array}{c}7-12 \\
\text { months }\end{array}$} & & & & & & $\begin{array}{c}7-12 \\
\text { months }\end{array}$ & & \\
\hline & & 1 year- & & & & & & 1 year- \\
\hline & & & & & 1 year+ & & & \\
\hline & & $1-3$ years- & & & & & & 1-3 year- \\
\hline & & & & & & & 1.25 years- & \\
\hline & & & & & & & $\begin{array}{l}1.25-5 \\
\text { years }\end{array}$ & \\
\hline \multirow[t]{2}{*}{$1-2$ years- } & & & $1-2$ years & $1-2$ years & & $1-2$ years & & \\
\hline & & & 2 years + & 2 years + & & 2 years + & & \\
\hline \multicolumn{9}{|l|}{ 2-4 years- } \\
\hline & $2-5$ years- & & & & & & & \\
\hline & & & & & & & & 3 year+ \\
\hline & & $3-5$ years & & & & & & \\
\hline \multicolumn{9}{|l|}{4 years +} \\
\hline & $.5-2$ years- & & & & & & & \\
\hline & 5 years + & 5 years + & & & & & 5 years + & \\
\hline
\end{tabular}

\section{Standards}

Standards are discussed in terms of the same three aspects related to these topic areas: coverage, questions, and response categories.

It is practical and reasonable to set a standard on coverage. Specifically, all systemwide on-board surveys by fixed-route agencies should cover all of these topic areas: trip purposes, access/egress, transfers, and frequency and duration of transit usage. Even if an on-board survey focuses entirely on customer satisfaction, for example, responses from these topic areas are critical to understand differences in customer satisfaction cross trip purposes, access/egress, transfer involvement, and transit usage.

However, it is impractical to specify standards for questions and response categories because of the wide variations that exist in current surveys. Agencies often want to compare survey results over time. Consistency in questions and response categories facilitates such a comparison. It is impractical also because transit agencies vary in the scope and scale of their operations, in their customers, and in their history. One would not want to list "more than 5 days a week" as a 
response category for a question on duration of transit usage when an agency operates 5 days a week. There is no reason to have "College" as one trip purpose when there is no college in the service area of an agency. It also is unnecessary to specify standards for questions and response categories because state-level measurement does not require that all response categories for a given question be identical in a survey instrument. Rather state-level measurement requires that the response categories for a given question from different agencies: 1) contain a common sub-set that is relevant for state-level measurement; or 2) be aggregatable to a common set of categories. The following discusses these minimum requirements for each topic area.

Trip Purpose. The topic area of trip purposes can be covered either through origin-destination purposes or through general purposes of a trip. In either case, the questions should be worded to solicit trip purposes for linked trips. In terms of origin purposes, for example, "Where did you come from before you got on this bus?" should be avoided. A better worded question would be: "Where did you come from before you got on the bus for this trip?" When origin and destination purposes are used, both origin and destination should be used.

All trip-purpose questions should at least include "Work," "School," "Medical and dental," and "Shopping" as four separate response categories. When trip purposes are solicited in terms of origin purposes and destination purposes, "Home" needs to be included as well. Different levels of school may be used by different agencies, but they need to be able to be aggregated. Among the 14 different patterns of response categories currently used for trip purposes in Florida, 10 use shopping as a separate category but 4 combines shopping with errands. It is proposed that shopping be a separate category. Errands (personal) can be a separate category or be part of the "Other" category.

Access/Egress. It is proposed that access/egress questions be specific to the subject trip. There is no single good reason to collect trip characteristics using a general question rather than a tripspecific question. A question to avoid would be: "How do you usually get to the bus?"

It also is proposed that access/egress questions focus on linked trips. As discussed in the previous section, the main difference in how access/egress questions are worded result from whether these questions focus on linked or unlinked trips. There are two potential reasons for collecting access/egress modes of unlinked trips.

- One reason is to compare differences in walk access/egress between the first boarding and transfer boardings. When access/egress questions are based on unlinked trips in current practice, however, such comparison was not made by any of the 25 survey studies.

- The other potential reason would be to measure the degree of transferring. However, measuring the degree of transferring was not the primary reason for including transferring in access/egress modes. Several agencies that include transferring in their access/egress questions also ask separate questions on transferring.

There are at least three reasons, on the other hand, that access/egress questions should not focus on unlinked trips. The primary interest in access/egress modes is at the two ends of a linked trip. In addition, most of the response categories in access/egress questions on unlinked trips (i.e., "Driving," "Riding as a passenger," and "Biking") become meaningless for transferring. Finally, 
some respondents may be confused between the access mode at the beginning of a linked trip and the access mode at the middle of this linked trip. As a result, transferring may not be accurately measured from an access/egress question on unlinked trips.

It is proposed that access/egress questions on linked trips should at least include driving, riding as a passenger in a passenger vehicle (being dropped off for access but being picked up for egress), and biking. Including biking as a separate access/egress mode would lead to information on the potential market of a bike-on-bus program. In addition, walking should be disaggregated by blocks and the walking categories can be aggregated into two levels: walking 3 blocks or less and walking more than 3 blocks. When access/egress questions are based on linked trips, walking typically captures over 90 percent for bus services.

Transfers. As proposed, transfers should be out of the access/egress questions. The particular questions on transfers still depend on what information on transfers is preferred by agencies. If the preference is to know the overall degree of transferring in its system, an agency should ask one single question. This single question can be a yes-or-no question or a question soliciting the total number of transfers for each linked trip. A yes-or-no question would be: "Do you need to transfer to complete this trip?" Otherwise, the question may be: "How many times do you need to board a bus to complete this trip?" If the preference is to know the transferring pattern across different routes, a pair of questions would be needed as Gainesville Transit did in its recent on-board survey: "Did you transfer to this bus?" and "Will you transfer to another bus to complete this trip?"

Frequency. For soliciting information on frequency of transit usage, the typical form and most of the variations in Table 8 serve their purposes. What is critical is to avoid questions that use response categories that cannot be aggregated to a common set for state-level measurement. The vast majority of the questions in Table 8 use response categories that state days of using transit per week. Questions that do not use response categories in terms of days of transit usage per week should be avoided. Two examples of such question are: "How many one-way bus trips do you make in a typical week?" and "How many trips do you make per week using public transportation?"

In terms of response categories, one important factor is that the question needs to be consistent with a set of response categories that state transit usage in terms of days per week (i.e., 1 day per week, 2 days per week, etc.). The only other factor is that the categories can be aggregated into three levels for state-level measurement. These aggregated categories are: more than 4 days per week, 1-4 days per week, and less than 1 day per week. Among the 22 different patterns of response categories in Table 11, 8 cannot be directly aggregated into these three levels $(2-3,7,9$, 13-14, 17-18). However, minor changes in these 8 patterns would result in patterns that can be aggregated into these levels.

Duration. Duration of transit usage is almost always collected through this question: "How long have you been using XXX?" In terms of response categories, the only important factor is that they can be aggregated into four levels for state-level measurement: less than 6 months, 6 months to 1 year, 1-2 years, and more than 2 years. Among the nine different patterns of response categories currently used in Florida (Table 12), five can be aggregated into these four levels (1-2, 4-5, and 7). One important point to make here is that many of the variations do not serve specific purposes. 


\section{Data Transmission}

Similar to the questions on the State's policy objectives, a reasonable approach for the state to gather the local estimates from individual agencies would be to require all transit agencies to submit a spreadsheet containing the local estimates each time a systemwide on-board survey is completed. The local estimates should be consistent with the final document that reports the results of the on-board survey. A template in Table 13 may be used for this purpose if trip purposes are general rather than in terms of origin purposes and destination purposes. This template would be part of an overall template including information in Table 6. If an agency asks an alternative question on transfers (e.g., How many transfers do you need to make to complete this trip?), it would still have the information for determining its local estimates for Q6.

Table 13. Template for Summary Data

\begin{tabular}{|c|c|c|c|}
\hline & Questions & Aggregated Categories & Local Estimates \\
\hline \multirow{5}{*}{ 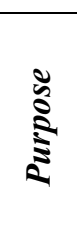 } & \multirow{5}{*}{$\begin{array}{l}\text { General: (Q3) What is the primary } \\
\text { purpose of this trip? }\end{array}$} & Work & \\
\hline & & School & \\
\hline & & Medical & \\
\hline & & Other & \\
\hline & & Total & $100 \%$ \\
\hline \multirow{14}{*}{ 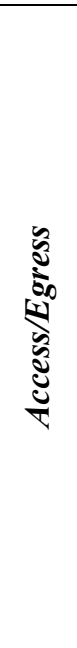 } & \multirow{7}{*}{$\begin{array}{l}\text { Access: (Q4) How did you get to } \\
\text { the stop for this trip? }\end{array}$} & Walked 3 blocks or less & \\
\hline & & Walked more than 3 blocks & \\
\hline & & Drove & \\
\hline & & Dropped off & \\
\hline & & Biked & \\
\hline & & Other & \\
\hline & & Total & $100 \%$ \\
\hline & \multirow{7}{*}{$\begin{array}{l}\text { Egress: (Q5) How will you get to } \\
\text { your final destination? }\end{array}$} & Walk 3 blocks or less & \\
\hline & & Walk more than 3 blocks & \\
\hline & & Drive & \\
\hline & & Picked up & \\
\hline & & Bike & \\
\hline & & Other & \\
\hline & & Total & $100 \%$ \\
\hline \multirow{3}{*}{ ș } & \multirow{3}{*}{$\begin{array}{l}\text { Transfers: (Q6) Do you need to } \\
\text { transfer to complete this trip }\end{array}$} & Yes & \\
\hline & & No & \\
\hline & & Total & $100 \%$ \\
\hline \multirow{9}{*}{$\frac{8}{5}$} & \multirow{4}{*}{$\begin{array}{l}\text { Frequency: (Q7) How often do you } \\
\text { ride the bus? }\end{array}$} & More than 4 days a week & \\
\hline & & 1-4 days a week & \\
\hline & & Less than one day a week & \\
\hline & & Total & $100 \%$ \\
\hline & \multirow{5}{*}{$\begin{array}{l}\text { Duration: (Q8) How long have you } \\
\text { been using transit? }\end{array}$} & More than 2 years & \\
\hline & & $1-2$ years & \\
\hline & & 6 months to 1 year & \\
\hline & & Less than 6 months & \\
\hline & & Total & $100 \%$ \\
\hline
\end{tabular}


If an agency solicits trip purposes in terms of origin purposes and destination purposes, it would need to use a separate template shown in Table 14. The rows represent aggregated categories on origin purposes, and the columns represent aggregated categories on destination purposes. The data from all 25 cells should add to 100 percent. If an on-board survey is perfect, the home-home cell should be close to 0 . In that case, the overall distribution of trip purposes would be those destination purposes when the origin purpose was home after rescaling to $100 \%$. In reality, however, the home-home cell may not be close to 0 . After rescaling to $100 \%$, the overall distribution in this case can be approximated by adding up two sets of percentages from this template: 1) those destination purposes when the origin purpose is home; and 2) those origin purposes when the destination purpose is home.

Table 14. Template for Summary Data on Origin-Destination Purposes

\begin{tabular}{|c|c|c|c|c|c|c|c|}
\hline \multirow[t]{2}{*}{ Question } & \multirow{2}{*}{$\begin{array}{l}\text { Aggregated } \\
\text { Categories }\end{array}$} & \multicolumn{6}{|c|}{$\begin{array}{c}\text { Destination Purpose: } \\
\text { (Q2) Where are you going on this trip? }\end{array}$} \\
\hline & & Home & Work & School & Medical & Other & Total \\
\hline \multirow{6}{*}{$\begin{array}{l}\text { Origin Purpose: } \\
\text { (Q1) Where did you } \\
\text { come from before } \\
\text { you go on the bus } \\
\text { for this trip? }\end{array}$} & Home & & & & & & \\
\hline & Work & & & & & & \\
\hline & School & & & & & & \\
\hline & Medical & & & & & & \\
\hline & Other & & & & & & \\
\hline & Total & & & & & & $100 \%$ \\
\hline
\end{tabular}

